Journal of Social Sciences (COES\&RJ-JSS)

ISSN (E): 2305-9249 ISSN (P): 2305-9494

Publisher: Centre of Excellence for Scientific \& Research Journalism, COES\&RJ LLC

Online Publication Date: $1^{\text {st }}$ January 2018

Online Issue: Volume 7, Number 1, January 2018

https://doi.org/10.25255/jss.2018.7.1.42.60

\title{
The Philosophy of Coexistence in the Interpretation of \\ Al-Maidah Surah (Chapter) \\ Ali Radi AbuZurayk as a case study
}

\author{
Dr. Zaid khalid Al-Zuriqat \\ Department of philosophy \\ School of Arts, \\ University of Jordan, Jordan
}

\begin{abstract}
:
This paper aims at inspecting the Holy Quran stands (especially in Al-Maidah) on conflicts and anarchies, that are effecting our region and the world, which claims that such conflicts are related to sect and religion differences. Instead religion being a factor to stabilize and relief societies from conflicts and anarchies, it has turned to be their stamina.

The paper concentrated on the possibilities of coexistence among the followers of different religions as presented by Ali Rida Abu-Zraiq in his recent book The Miracle of Quran's Names of Chapters (2017). In His book he presented a new, and different, interpretation of Al-Maidah Surah in accordance semantics and syntaxes. Hence, this paper tried to compare such interpretation with two other interpreters: Sayd Qutob as a version of Sonnies and Mohammed Husain Tubtabaei as a version of Shieats.

The paper concluded that the new interpretation of Al-Maidah is different from all previous interpretations. While the old interpretations would present justifications for conflict, killing and exclusion; Abu-Zraiq's interpretation would present a totally different perspective of the Al-Maidah, presenting a bright picture of the possibility of coexistence among different religions within the same society, showing that the Chapter clearly indicates the way to resolve any possible conflict among them. Hence, in accordance with such interpretation, the religious differences within the society will bring about the need for respect and compassion among them, and a motivation to the followers in seeking God's obedience.

Keywords:

Coexistence, Interpretation of Quran, Ali Abu Zuragk, Al- Maidah Chapter (surah)

Citation:

Al-Zuriqat, Zaid khalid (2018). The Philosophy of Coexistence in the Interpretation of AlMaidah Surah (Chapter) Ali Radi AbuZurayk as a case study; Journal of Social Sciences (COES\&RJ-JSS), Vol.7, No.1, pp:42-60; https://doi.org/10.25255/jss.2018.7.1.42.60.
\end{abstract}




\section{فلسفة التعايش في تأويل سورة المائدة}

$$
\begin{aligned}
& \text { در اسة علي راضي أبو زريق انموذجاً } \\
& \text { الدكتور زيد خالد زريقات الإنيق النيات } \\
& \text { الجامعة الأردنية_كلية الآداب ـ قسم الفلسفة }
\end{aligned}
$$

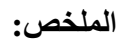

هدفت هذه الدراسة إلى معرفة موقف القرآن الكريم (سورة المائدة خصوصاً) من الصراع والفنت التي تجناح التخاح

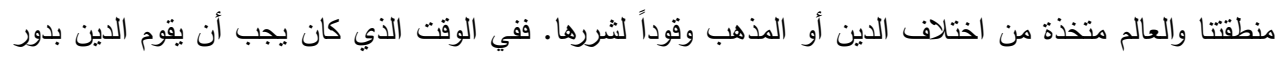

$$
\text { العزاء والتخفيف من الصراع والفتن صار هو الوقود لهما. }
$$

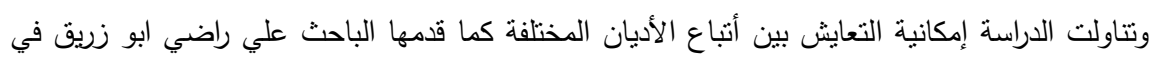

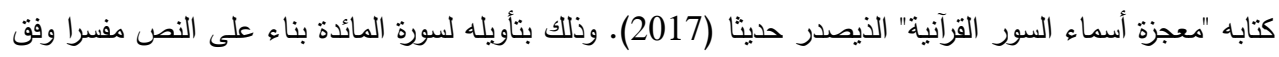

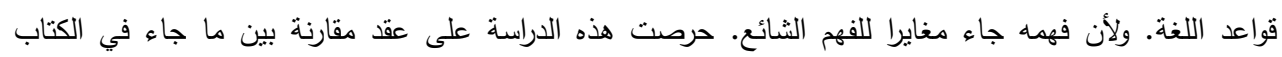

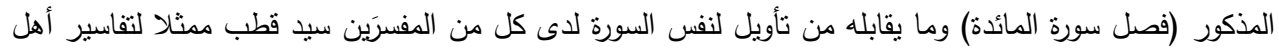

$$
\text { السنة، ومحمد حسين الطبطبائي ممثلا لمفسري الثنيعة الاثثي عشرية. }
$$

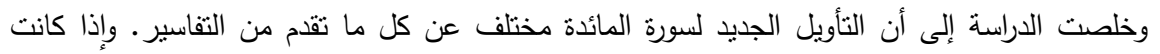

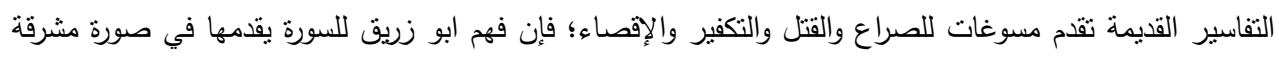

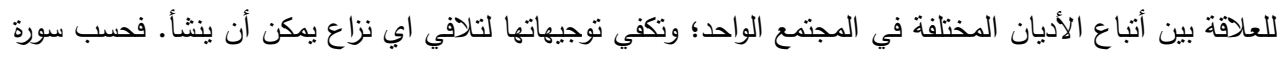

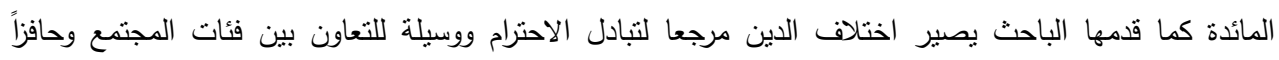
لتنافسها في طاعة الله كل" على دينها.

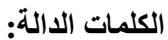
التعايش، تأويل القرآن ، علي راضي أبوزريق، سورة المائدة

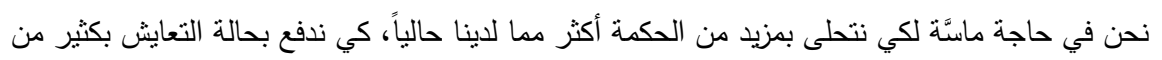

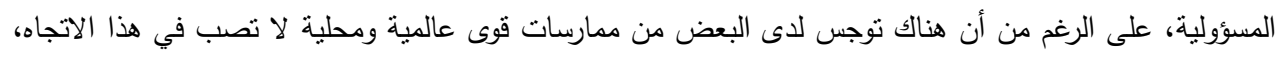

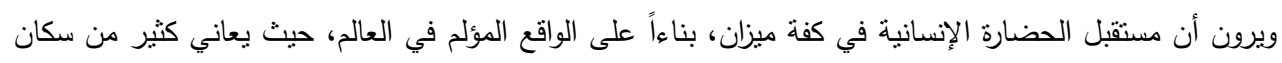

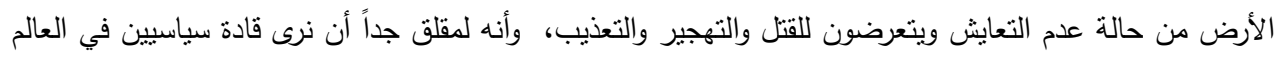

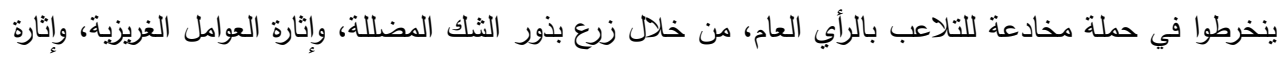

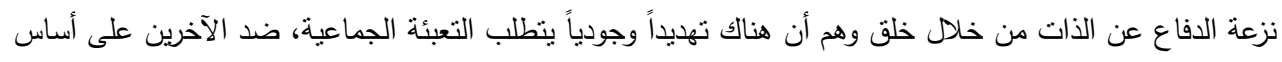
من العرق أو الدين، لتحقيق مأرب سياسة رخيصة.

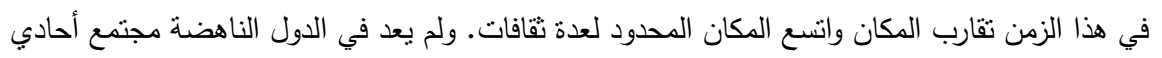

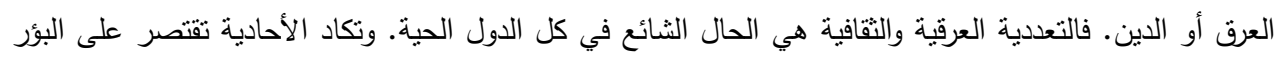

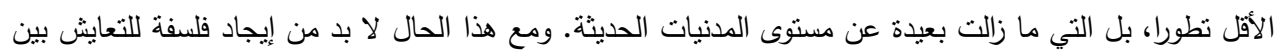

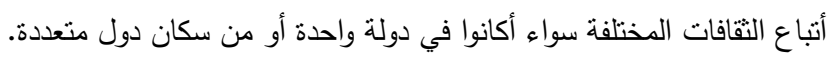

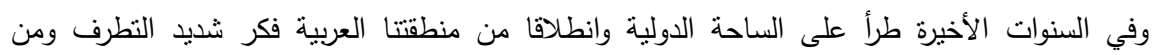

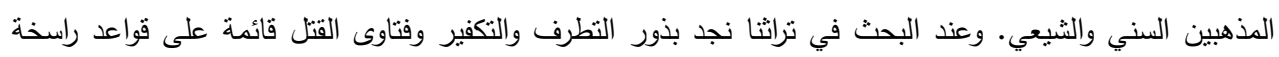


The Philosophy of Coexistence in the Interpretation of Al-Maidah Surah...

انطلاقا من تفسير آيات في القرآن الكريم. مما بحتاج ردا قرآنبا بعادل بقوته وصلابته رسوخ قواعد تلك الفتاوى التي

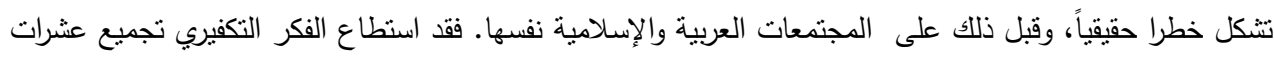
الآلاف مع داعش واضعافهم مع حشود إيران للمشاركة بقتال يقوم على تكفير الآخر واستباحة دمه وماله بناء على والِ فتاوى علماء كبار في المجتمعين الإسلاميين السني والثيعي. والتكفير ليس مقصورا على المسلمين بل هو المشترك الوحيد بين كل المؤمنين بالأديان السماوية (كما تعرفه معظم القواميس اللغة الإنجليزية تحت كلمة - Infidel). ولكنا هنا معنيين أكثر بشعوبنا ومصادرنا الثقافية. ونحن نطالع من نماذج التكفير في فكرنا ما كتبه قطب في ظل الآية 55 من سورة يوسف:"وهؤلاء لايققونبهذا الدينعندحدودأرضمعينة؛ولا عندحدودجنسمعين؛ولا عندحدودقومأولونأولغةأومقومواحدمنتلكالمقومانال

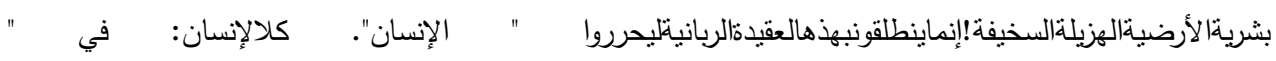

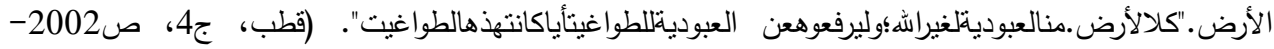

وفي

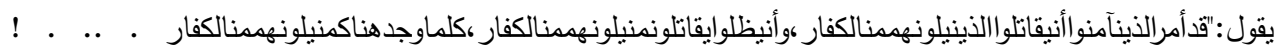

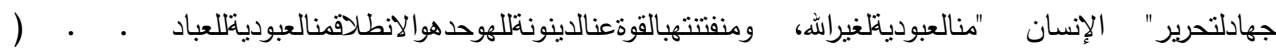

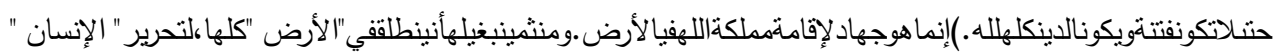

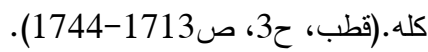

وليس سيد قطب وحده من يقول هذا. فقد راجعت تفسير هذه الآية (123: التوبة) في مائة تفسير من تفاسير القرآن ينتمي واضعوها لكل مذاهب الأمة. فكان الفهم نفسه مع تفاوت بسيط بدرجة حدة اللغة. فالطبري صاحب جامع الييان في تفسير القرآن:يقول:"يا أيها الذين صدّقوا الله ورسوله قاتلوا من يلونكم من الكفار". يقول: ابدعوا

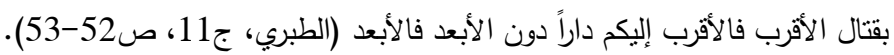
أمّا الثيخ محمد سيد طنطاوي (ت:2010م) وهو المعروف باعتداله يقول في التفسير الوسيط:" لأن القتال شرع لتأمين الدعوة الإسلامية، وقد كانت دعوة الإسلام موجهة إلى الأقرب فالأقرب، فكان من الحكمة أن يبدأوا قتالهم

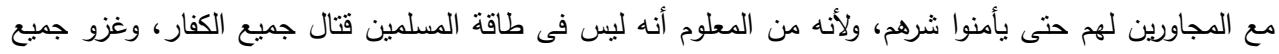

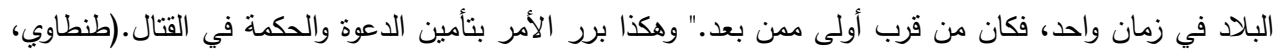
ص428-429).

من جانبه محمد حسين الطباطبائي وهو شيعي إيراني يقول في تفسيره الميزان:" أمر بالجهاد العام الذي فيه

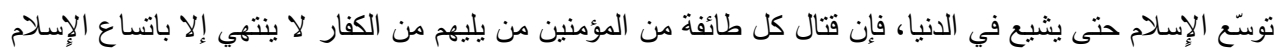

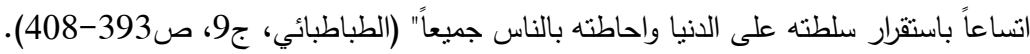

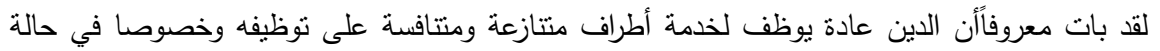

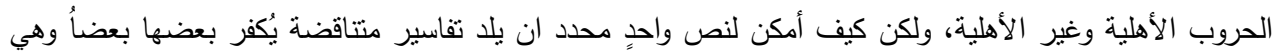
تتبع ديناً واحداً

إن اختلاف التفسيرات البشرية للنص الديني شائع بين البشر ـ أشار إليه القرآن بحق أنباع الأديان السابقة

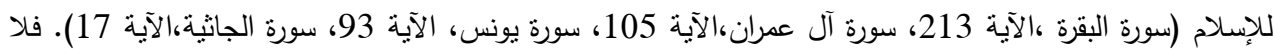
عجب أن يتعرض النص القرآني لنفس الأعراض فيختلف عليه أتباعه. 
إن مما ساعد على اختلاف تأويلات القرآن وتعددها أن القرآن نزل آيات منجمات لمعالجة مشكلات محددة

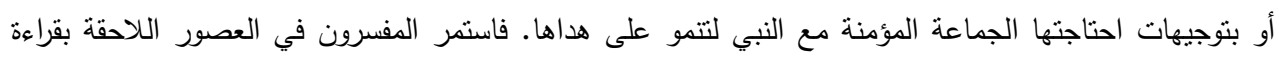

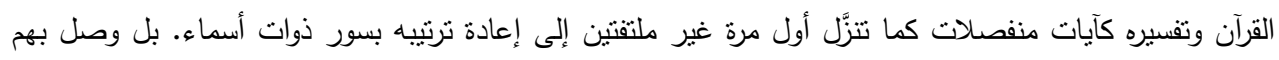

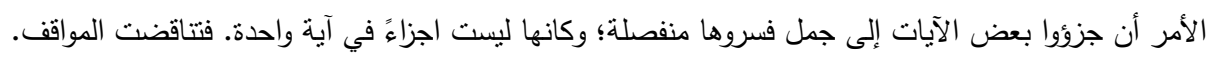

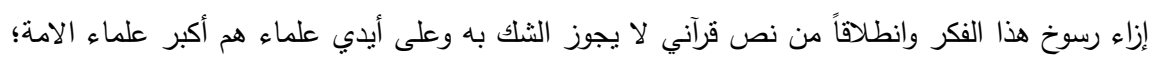

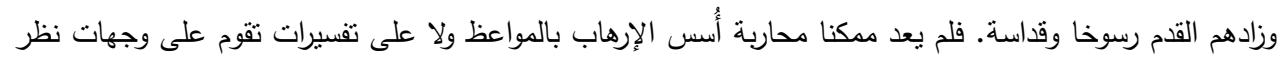

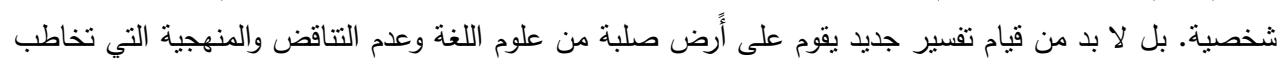

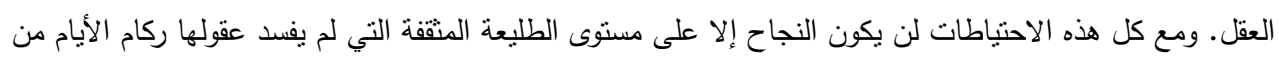

الفتاوى والثفاسير غير السليمة. وقد تصدى السيد أبو زريق لهذه المهمة. وبعقلية الباحث العلمي وضع كتابه "معجزة أسماء السور

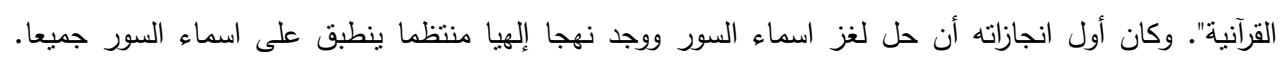

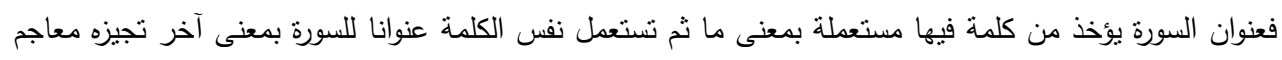

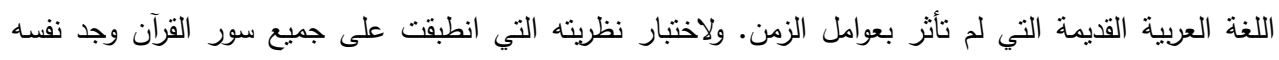

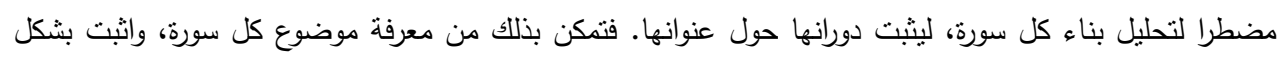

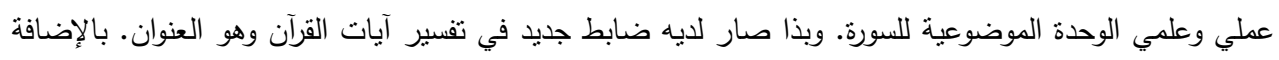

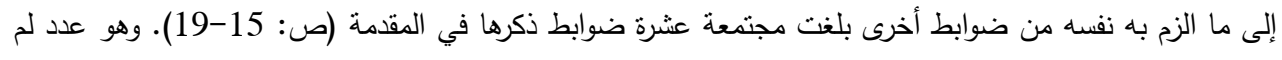

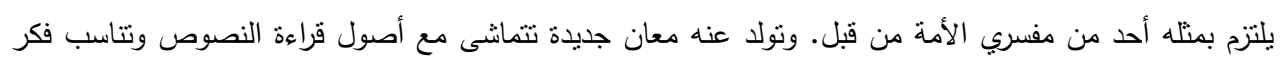

$$
\text { العصر الحديث وظروف تقارب شعوب الأرض ونعاونها. }
$$

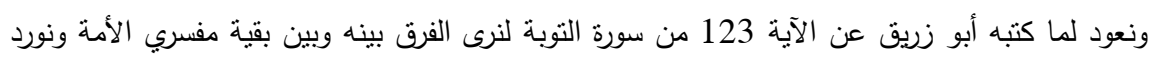

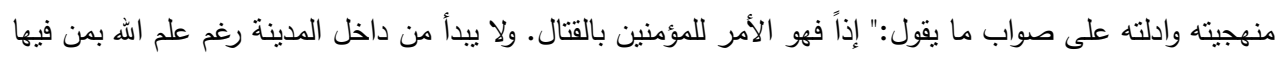

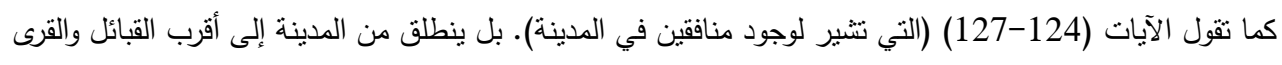

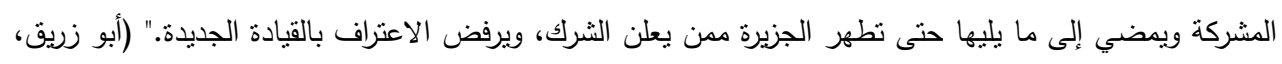

وبذا يفهم أبو زريق أن المقصود بقتال التوبة هم مشركوا الجزيرة العربية؛ والمطلوب الرئيسي اعترافهم

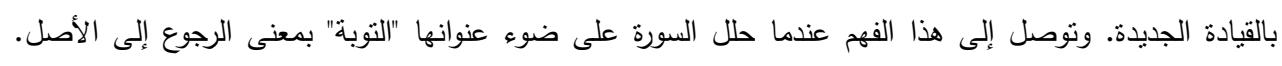

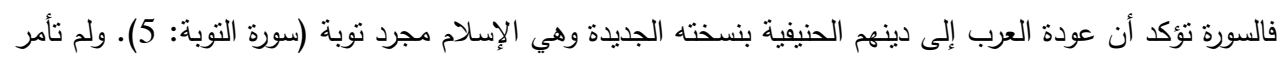

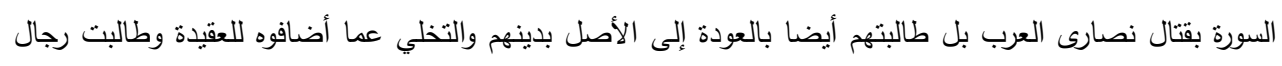

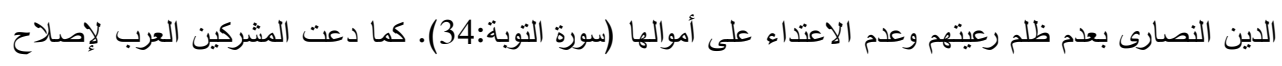

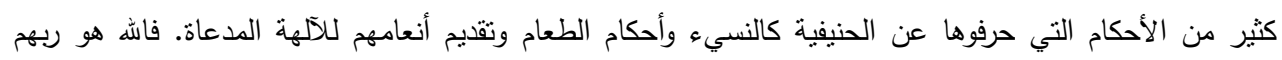
الواحد وله وحده تكون العبادة والطاعة والتقدمات.

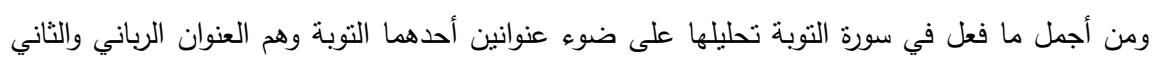

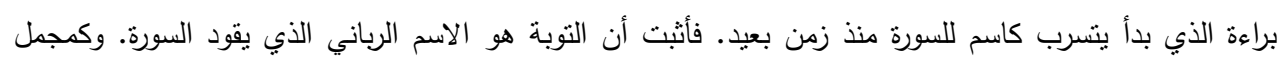

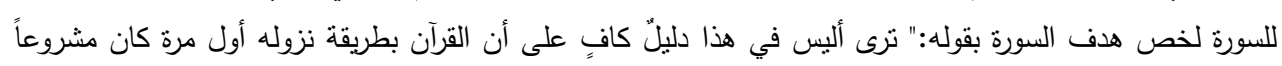


The Philosophy of Coexistence in the Interpretation of Al-Maidah Surah...

قومياً سياسياً؟ وأن التركيز على غزوة العسرة، وتثديد أمر اله على تتفيذها واعنبارها مقياساً لتقييم المؤمنين في هذه

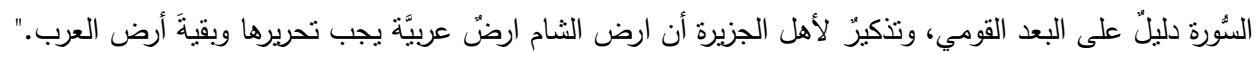

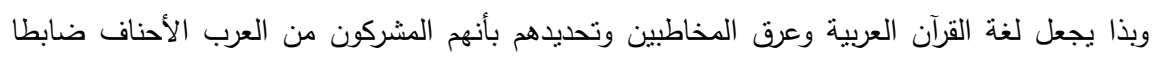

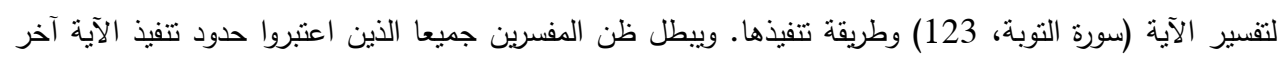

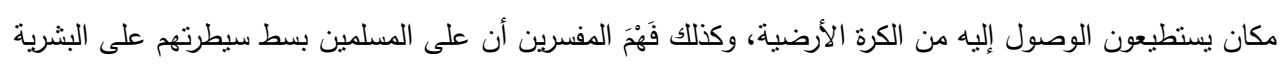

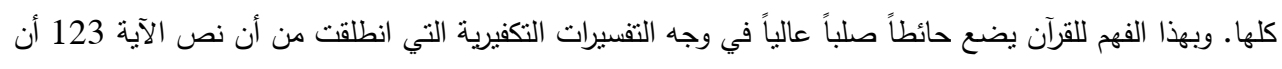

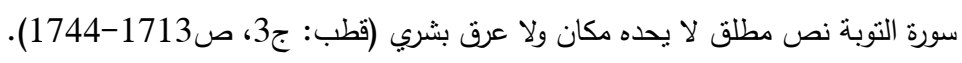

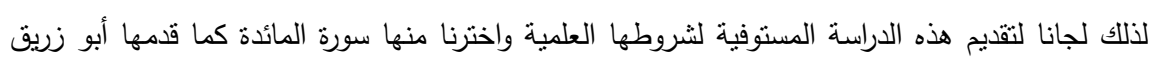

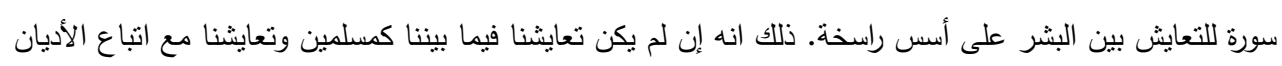

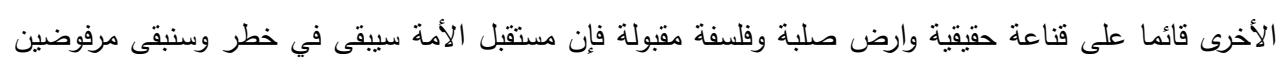
من كل شعوب الأرض. إن البحث بروم إلى تقديم صورة جديدة لفكرتي التنامحوالتعايش في سورة المائدة كما فسرّها علي راضي أبو زريق ونحن نقف في عرض فكرهعند محورين هامين":

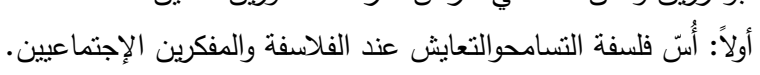

ثانياً: مقومات التسامحوالتعايش في سورة المائدة عند علي راضي أبو زريق مقارنةبتنفاسير سابقة ومعاصرة، وعلى ضوء رؤئية فلاسفة ومفكرين غربيين وعرب. ثم الخاتمة التي تحمل جملة استتاجات استخلصها الباحث.

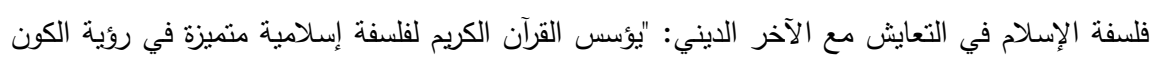

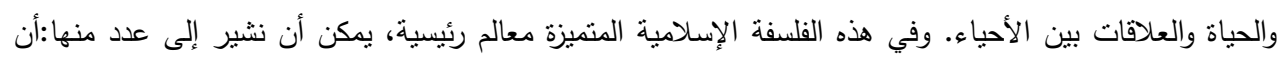

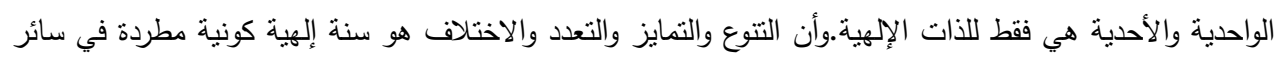

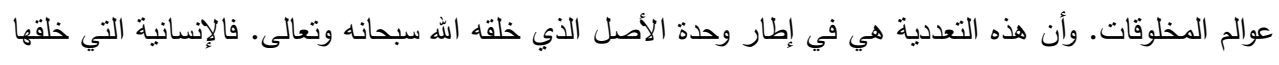

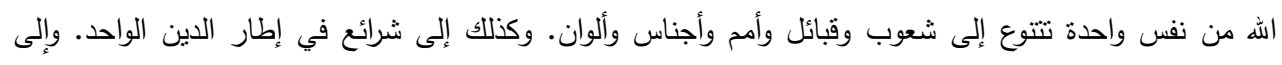

*علي راضي ابوزريق: مفكر اردني ولد 1945، حصل على البكالوريوس في العلوم الزراعية من الأزهر الثريف ثم ثماعثي

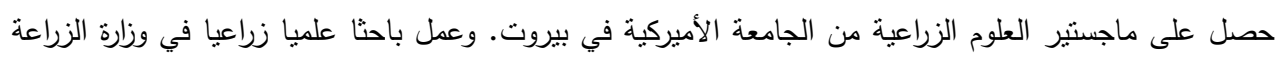

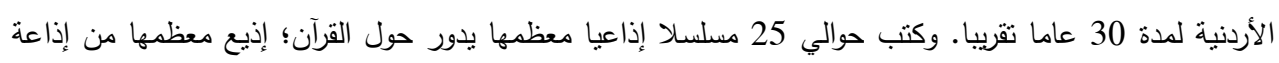

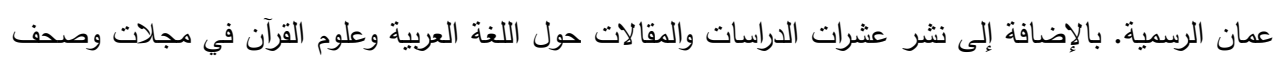

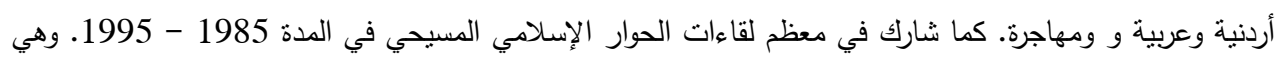

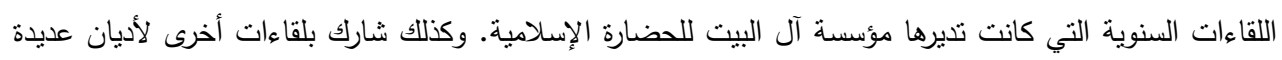

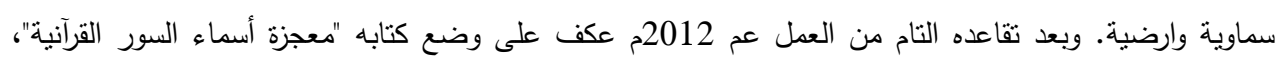

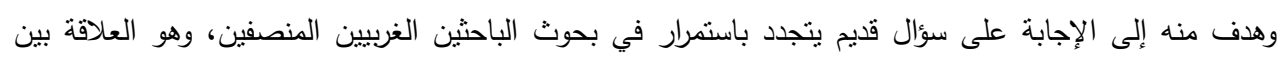
عنوان السورة القرآنية وموضوعها بل مواضيعها. 
مناهج، أي ثقافات وحضارات في إطار المشترك الإنساني الواحد، الذي لا تختلف فيه الثقافات. كما تنتوع إلى عادات وتقاليد وأعراف منمايزة حتى داخل الحضارة الواحدة، بل والثقافة الواحدة.

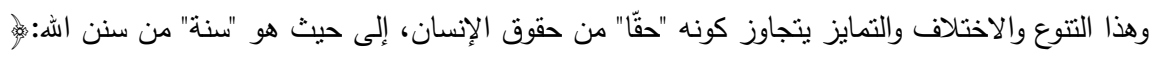

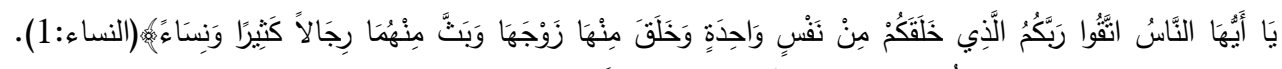

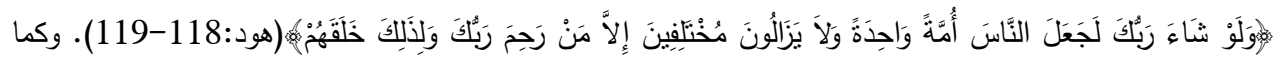

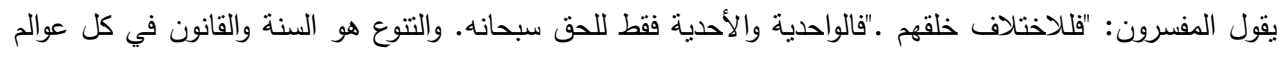

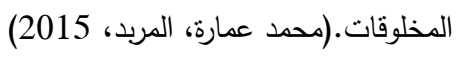

يُنظر إلى التعصب بمقابل مفهوم التسامح أو التعايش بوصفه ظاهرة اجتماعية شُديدة الخطورة، وبخاصة

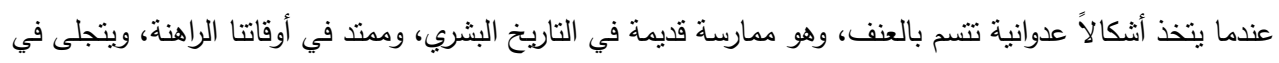

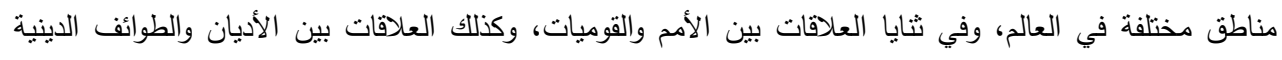

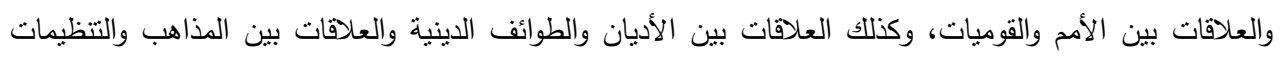

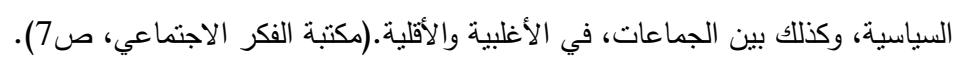

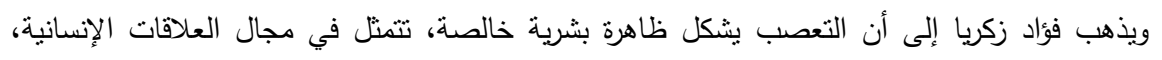

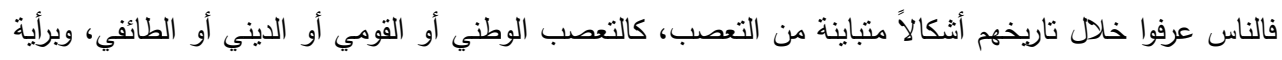

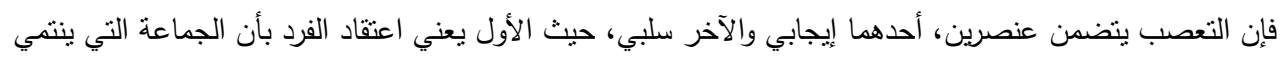

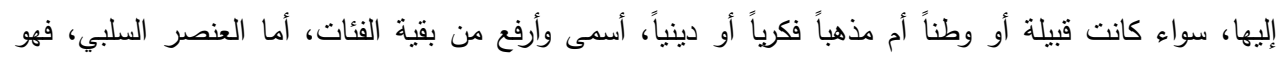

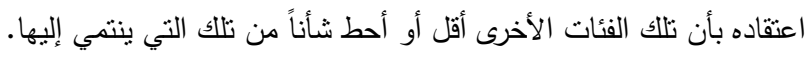

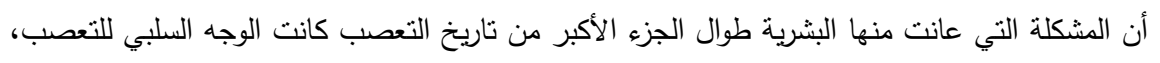

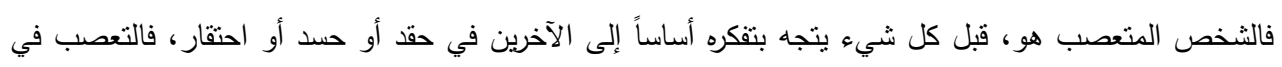

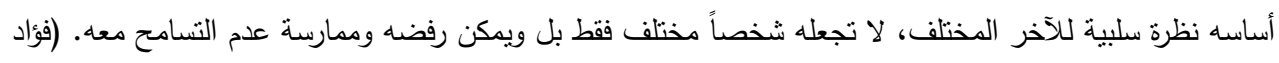

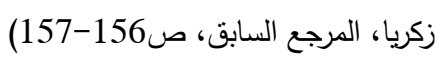

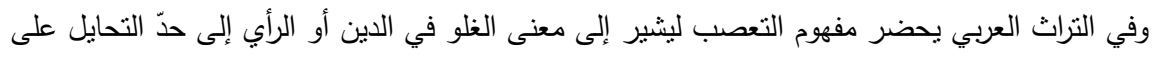

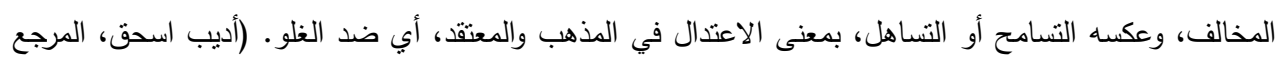

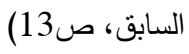
والتساهل على حد تعبير أمين الريحاني هو التسامح بوجود ما يخالف والاعتراف بذللك، أي أن التناهل

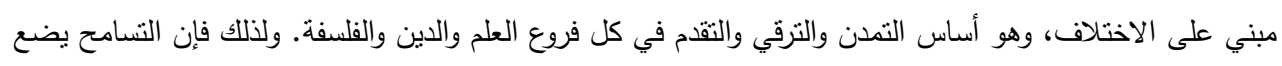

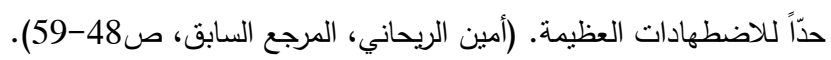

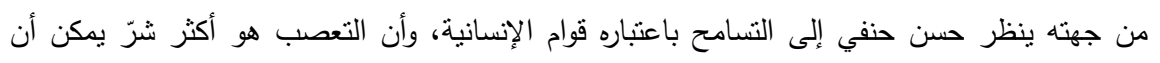

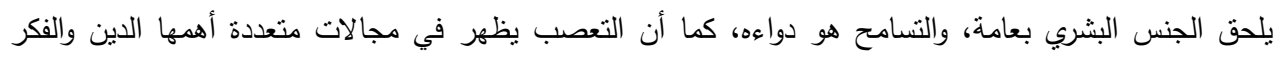

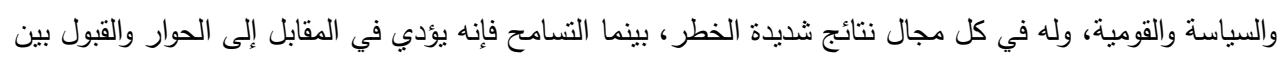

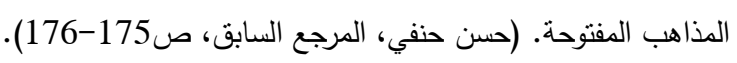

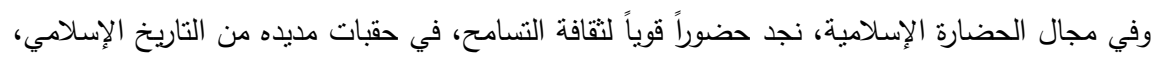
أمّا ثقافة الانغلاق والتعصب والعنف، فهي من إفرازات عصور الانحطاط الفكري والديني، التي ورثت ثنافتتا العربية 
The Philosophy of Coexistence in the Interpretation of Al-Maidah Surah...

الإنلامية المعاصرة بعضاً منه. ولا بُّْ من مدّ جسور الحوار والتواصل والتعايش، والانفتاح على الرأي المخالف وقبول

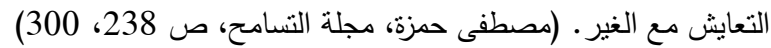

فإن الحضارة المنفتحة هي وحدها القادرة على الاستمرار والبقاء وعليه فإن المشترك الإنساني، هو تلإنك القيم

الإنسانية الني نثكل القاسم المشترك بين مختلف الأديان والحضارات، والتي هي نابعة من حاجة الإنسانة الفطرية،

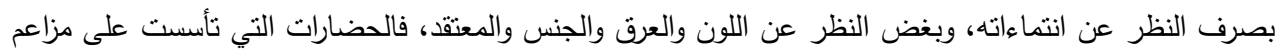

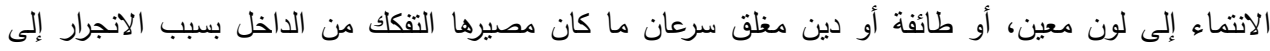

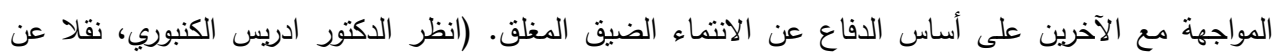

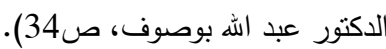

رئيس مجلس أمناء المعهد الملكي للاراسات الدينية يرى قبول التعددية والإقرار بالتتوّع واحترام حقوق الغير ،

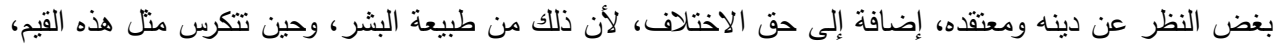

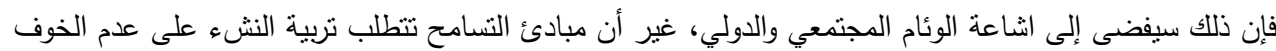

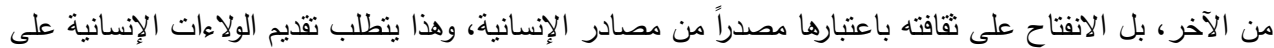

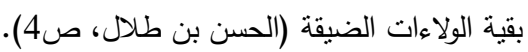

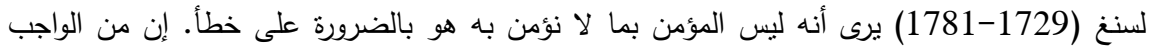

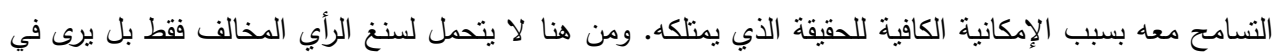

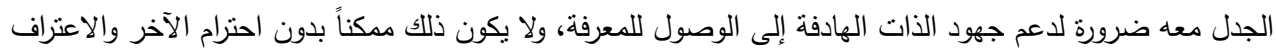

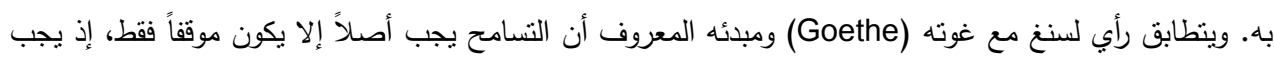

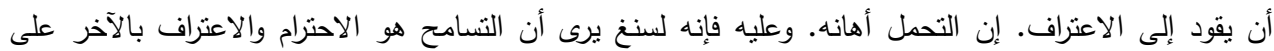

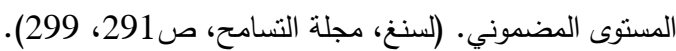
يرى راينر فورست (Rainer Forst) بأن النسامح مؤسس أخلاقياً للاحترام المتبادل للأفراد أو المجموعات

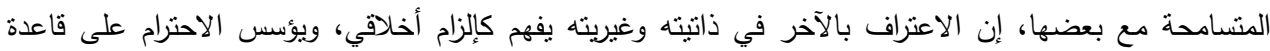

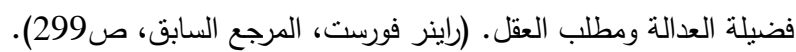

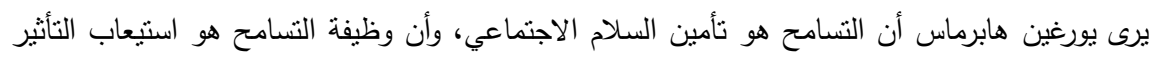

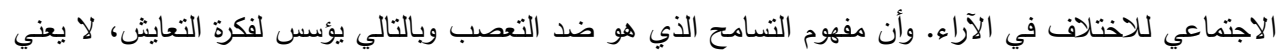

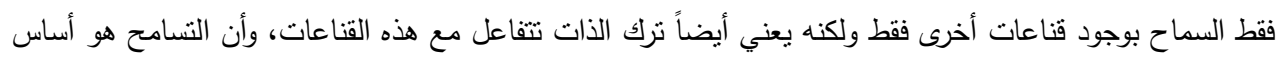

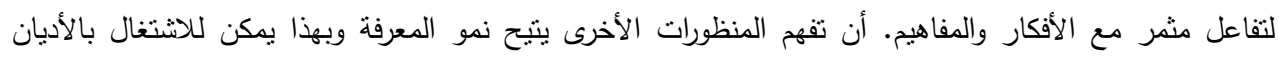

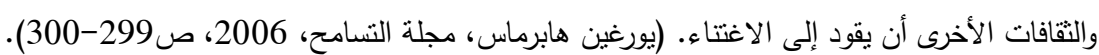

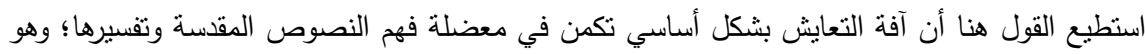

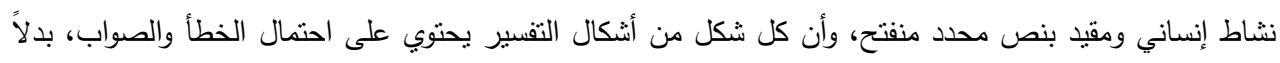
من احتمالية واحدة صحيحة. حيث أن كل تفسير يعكس تغيرات مستمرة في الزمان والمكان، وعدم فهم ذلك يعكس كسلاً في التفكير، ذلك فإن المستجد المعرفي والحياتي يدخل في فهم النص دون الوقان التوع في التتاقض (الجابري،

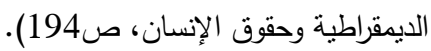
في هذا البحث سنلقي الضوء على فلسفة التعايش في سورة المائدة كما يراها علي أبو زريق في مؤلفه

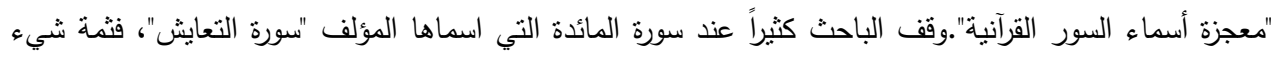


شدني في الفهم والتفسير فيها، وكأنه يخاطبنا ويوقظ فينا شيئاً هاجعاً، بما فيها من منهج للتعايش، ينبغي اتباعه، وفهماً شاملاً ومترابطاً للتعايش، يغرس الحب والمودة، بين الناس بما ينسجم مع رسالة القرآن الكريم.

أس فلسفة التعايش في القرآن الكريم في ضوء مقاربة أبو زريق:

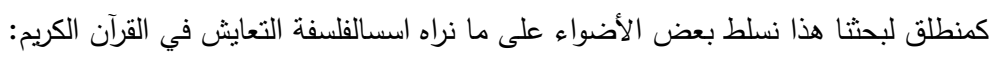

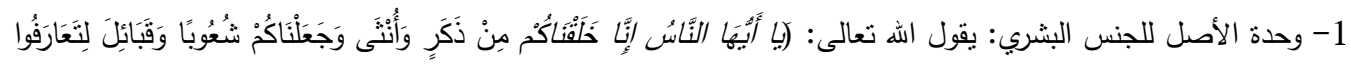

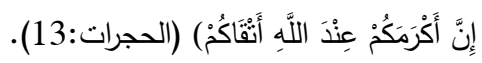

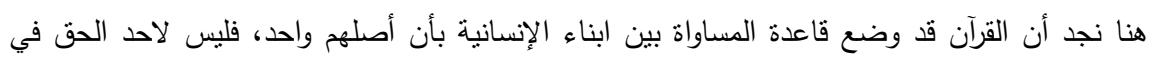

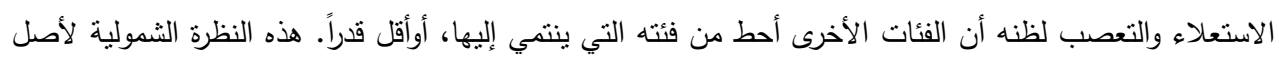

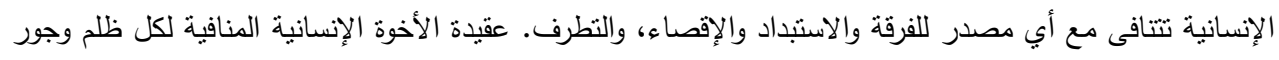

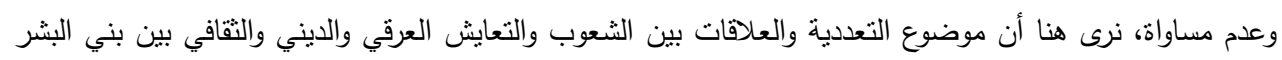

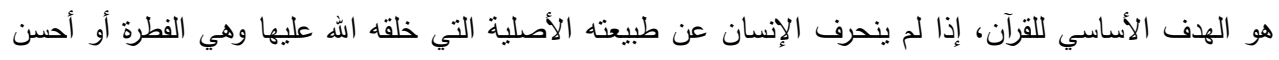

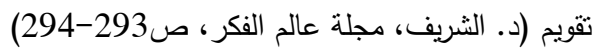

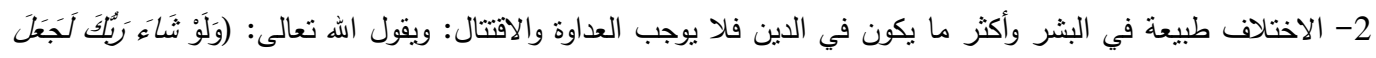

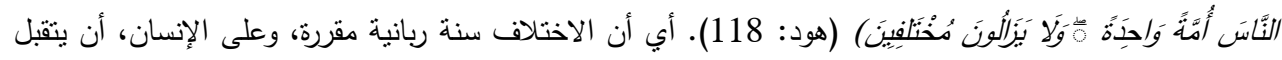

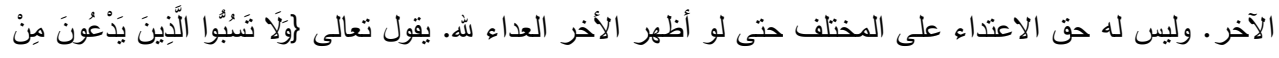

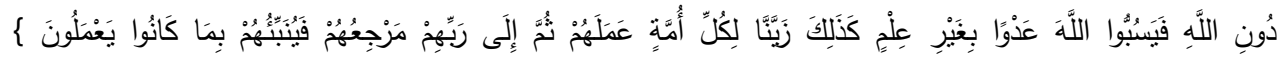

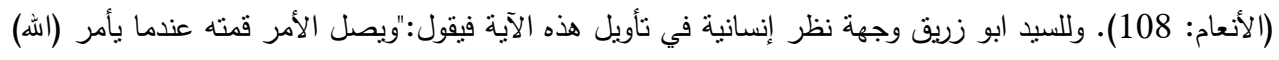

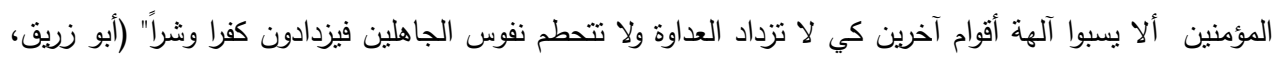
ص 160). 3- العفو والتنامح لصالح التعايش مع ما لا يضر بالمجتمع: يوجه الله نبيه لغض النظر عن خيانات اليهود أكبر اقليات

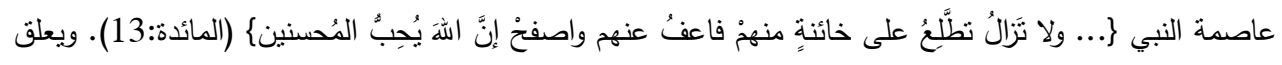

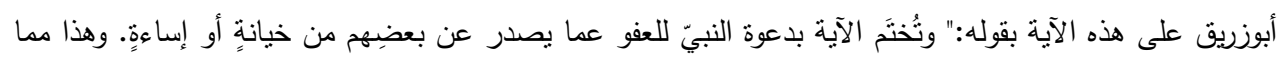

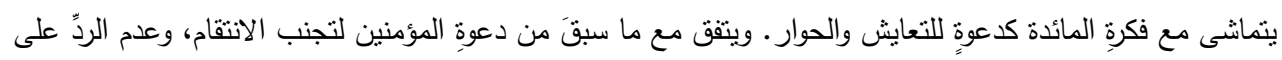

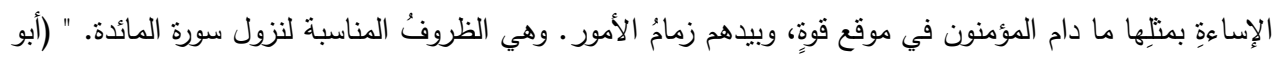
زريق، ص133).

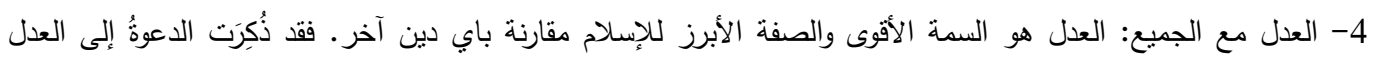

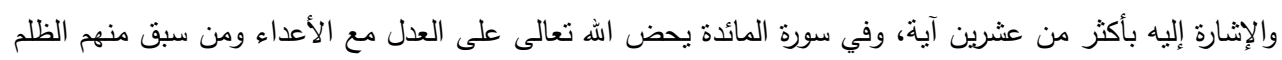

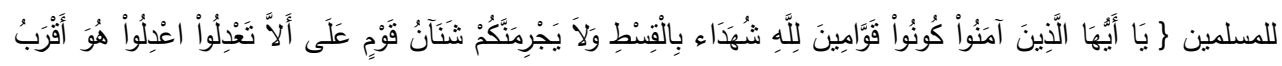

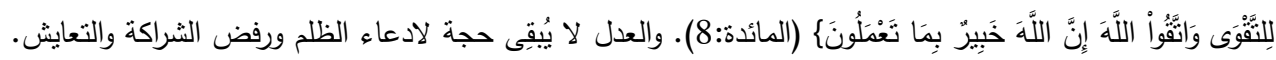

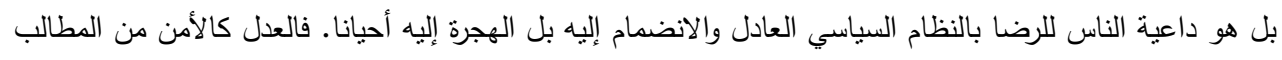

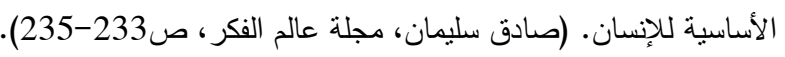

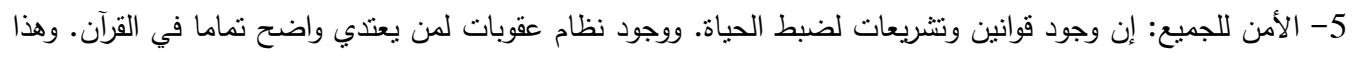

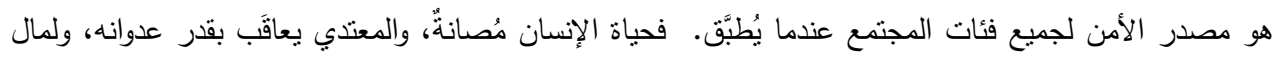


The Philosophy of Coexistence in the Interpretation of Al-Maidah Surah...

الإنسان حرمثُه وتصل عقوبة السرقة إلى قطع يد السارق، ولكل اعتداءٍ آخرَ عقوبتُّكافئَة. حتى سمعة الإنسان مصانة

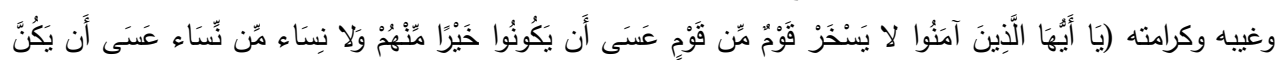

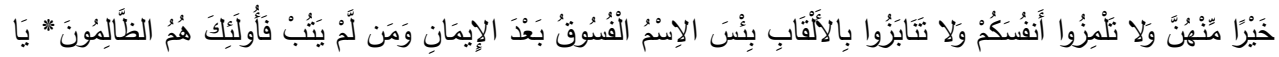

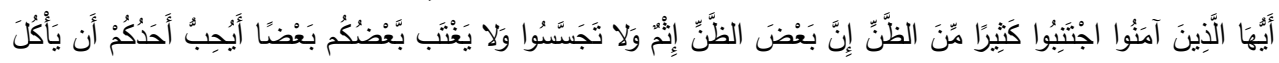

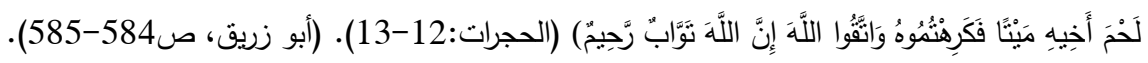
فلسفة التعايش في سورة المائدة:

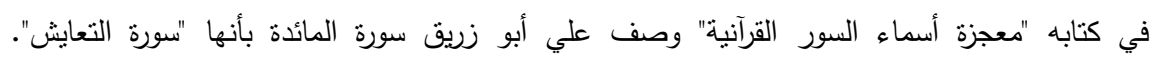

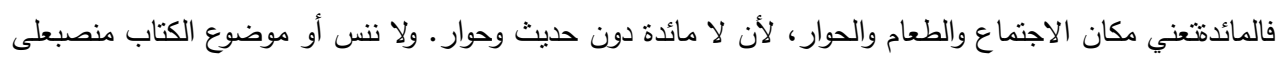

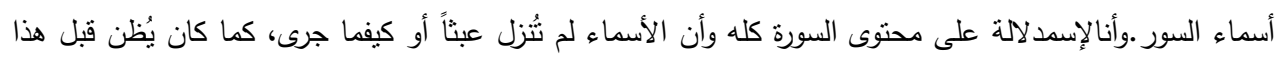
الكتاب.

ولإثبات وجهة نظره أجرى المؤلف تحليلاً للسورة على ضوء عنوانها وقال "كعنوان للسورة جاءت بمعنيين

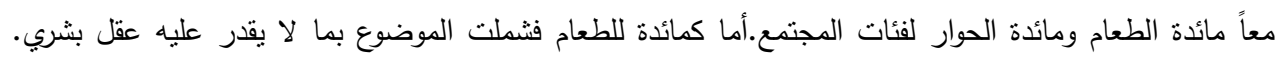

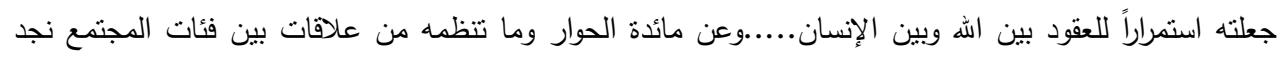

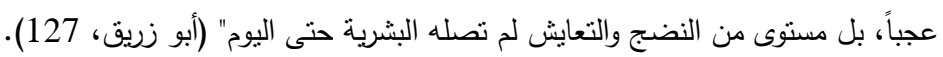

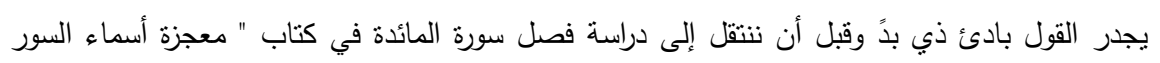

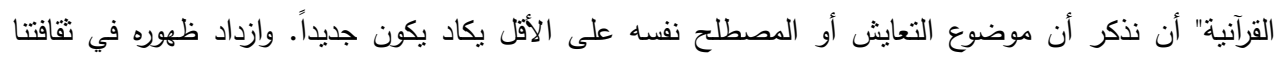

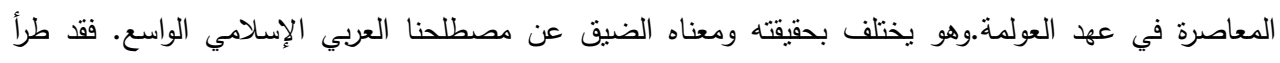
المصطلح المقابل باللغة الإنجليزية(co-exist) حوالي منتصف القرن العشرين على يد القيادة القيادة السوفياتية ليعني إمكانية

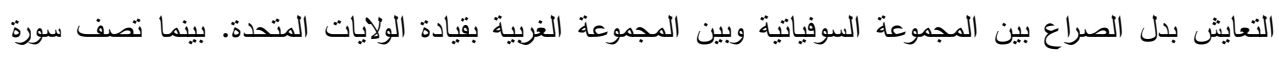

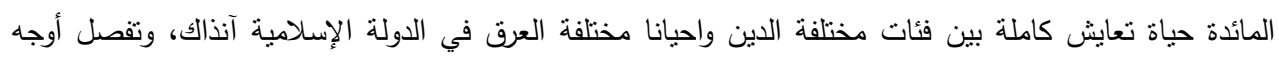

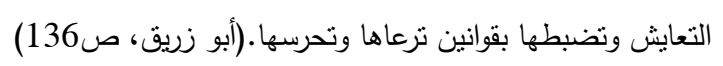

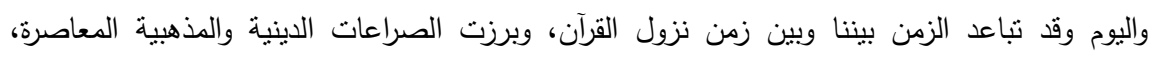

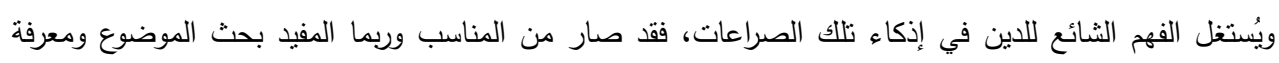

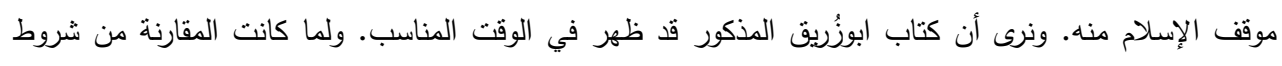

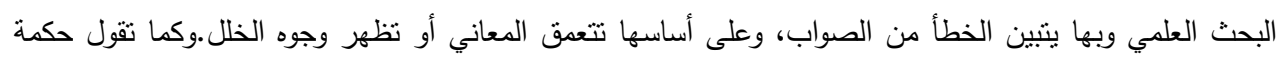

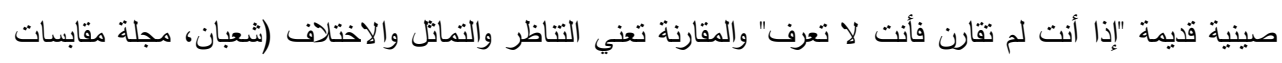

$$
\text { حضارية، ص16). }
$$

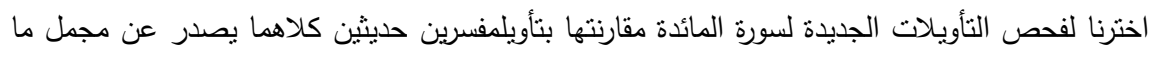

$$
\begin{aligned}
& \text { قالت المفسرون قبله، وكلاهما باحث ذو روية فكرية، مما يبعث روحاً في تفسيريهما. والمفسران المرجعان هما: }
\end{aligned}
$$

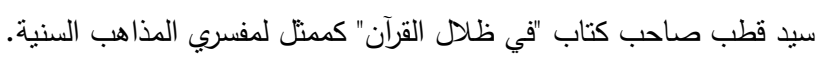

$$
\begin{aligned}
& \text { ومحمد حسين طباطبائي صاحب كتاب "الميزان" كممنل لمفسري المذاهب لهن الثيعية. } \\
& \text { وكلاهما ممن عاش وتوفي في القرن العشرين. } \\
& \text { أبرز معالم فلسفة التعايش في سورة المائدة: }
\end{aligned}
$$


أولاً: مائدة اللقاء والاتفاق: من عنوانها اكتثف ابو زريق في السورة أهم قواعد التعايش. يقول " وكعنوان للسورة جاءت

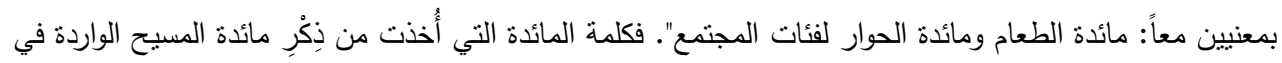

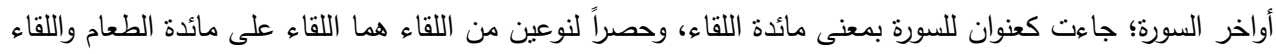

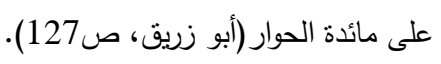

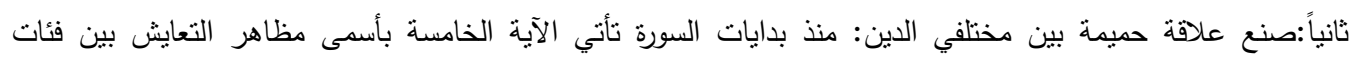

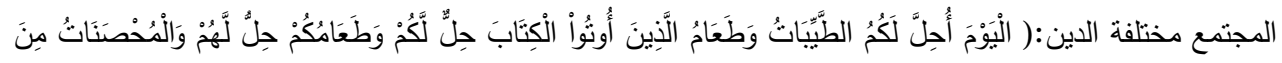

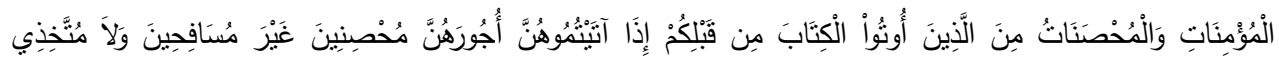

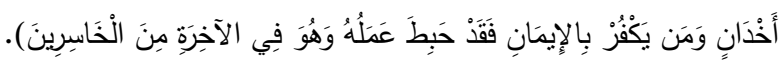

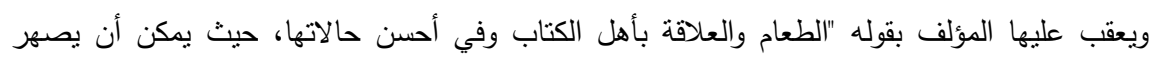

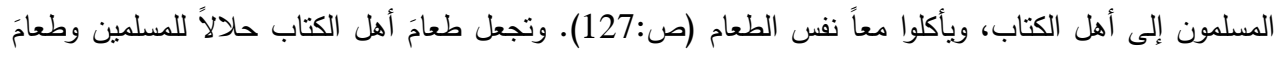

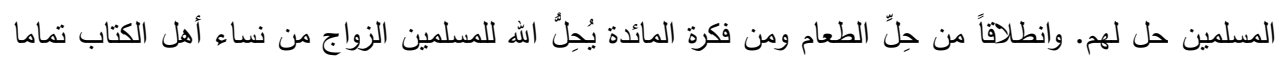

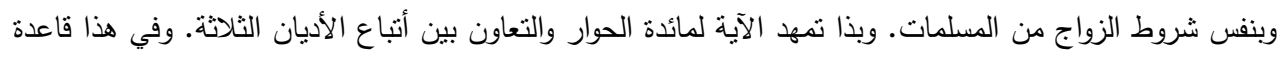

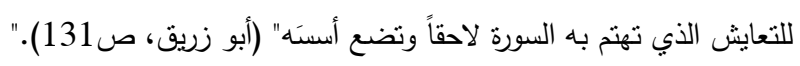

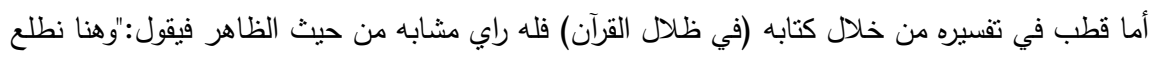

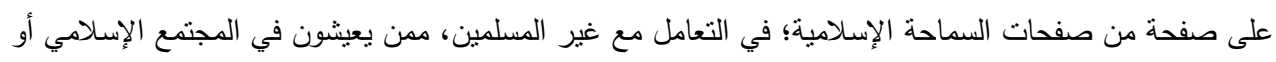

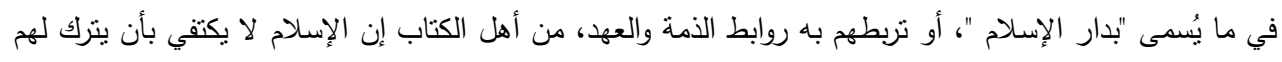

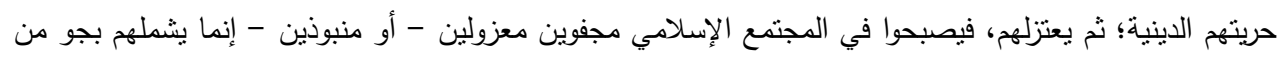

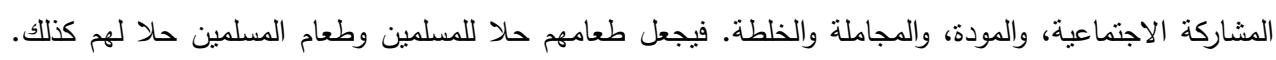

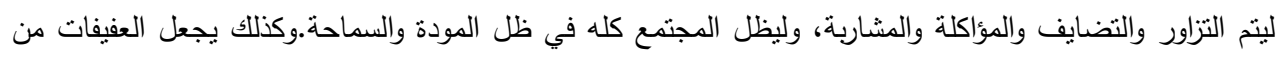

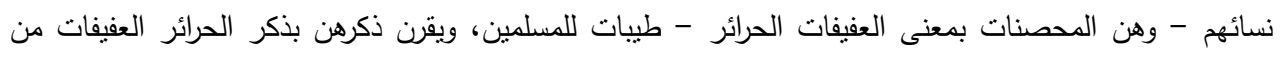

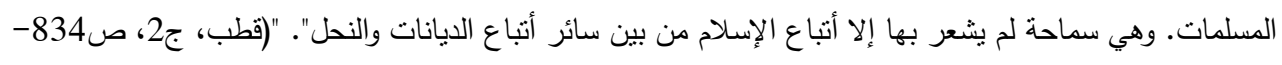

وقلنا إن رأيه مشابه من حيث الظاهر ، لأنا سنطلع لاحقاً على آراء له مناقضة تماماً.

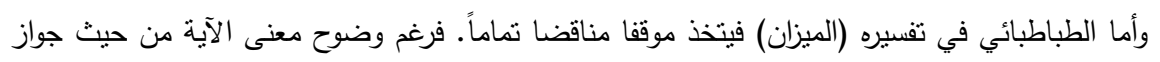

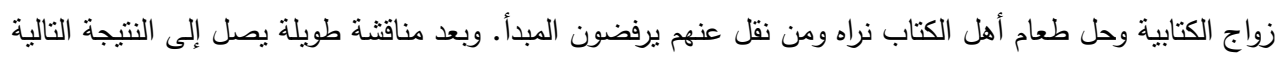

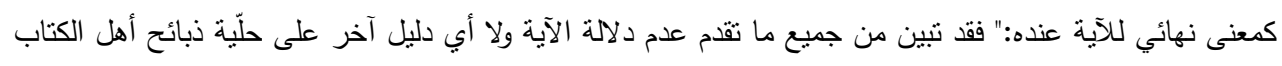

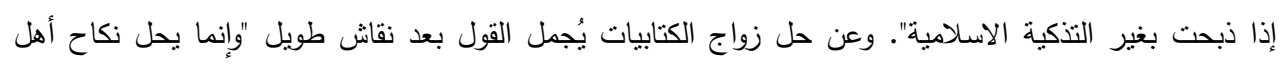

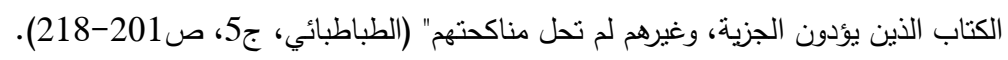

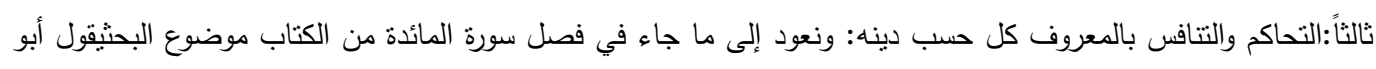

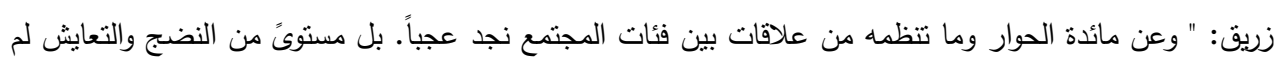

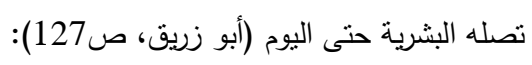

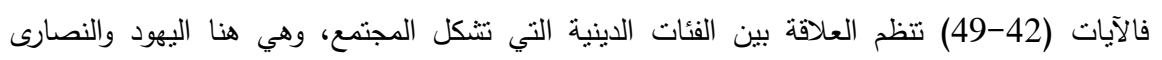

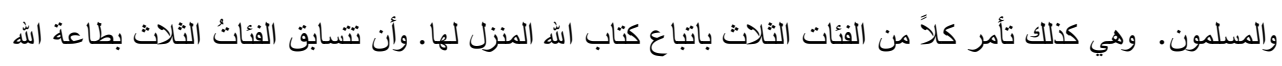

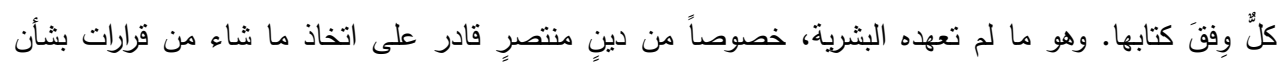


The Philosophy of Coexistence in the Interpretation of Al-Maidah Surah...

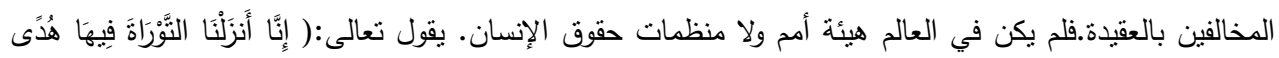

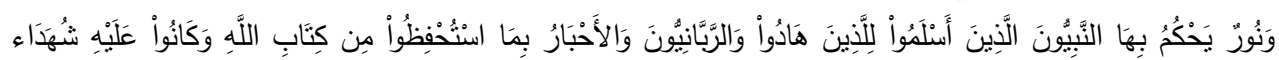

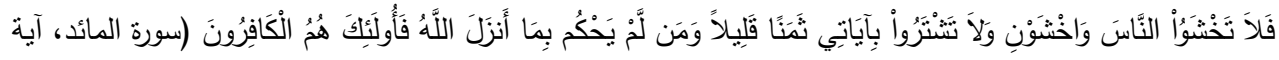

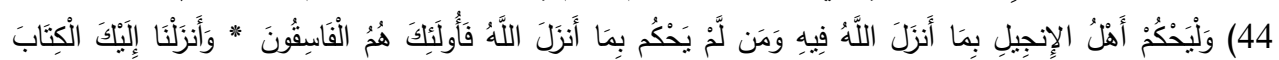

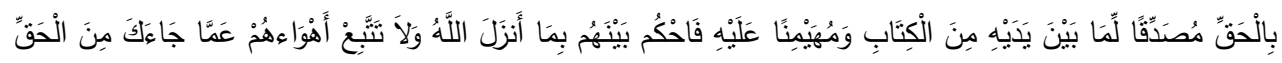

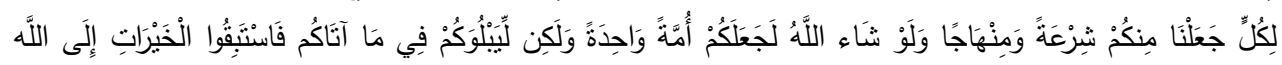

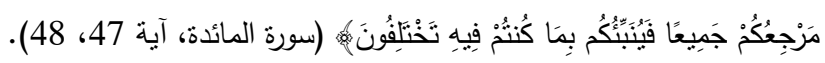

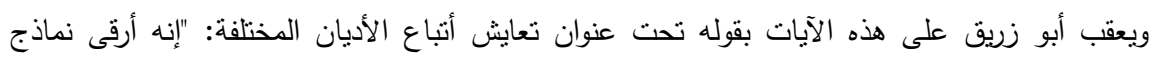

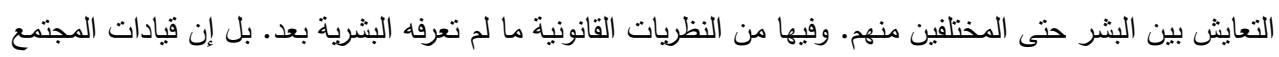

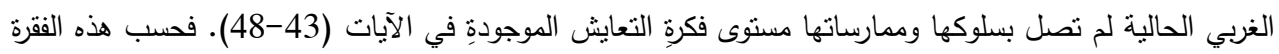

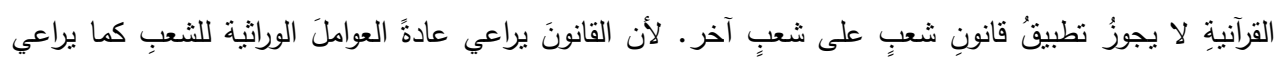

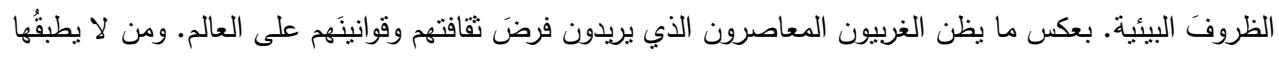

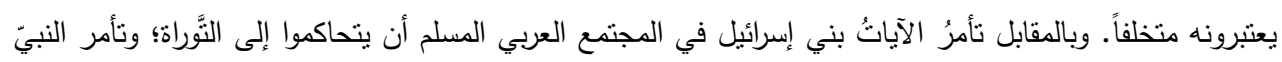

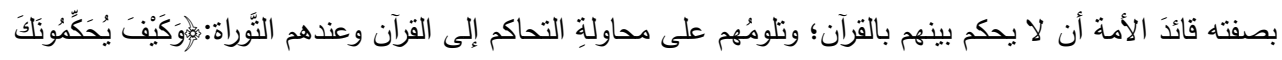

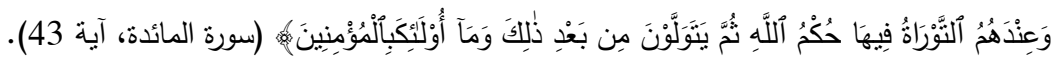

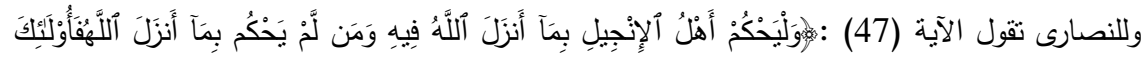
هُهُ الْفَفْبقونَنَهُ. ويضيف أبو زريق توضيحا لاختلاف القوانين بين الفئات الثلاث:" لعلمه اله تعالى باختلاف ظروفهم وما

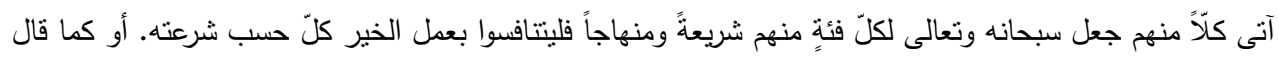

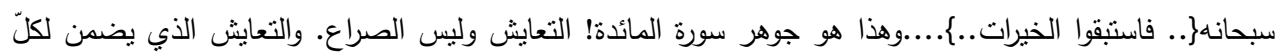

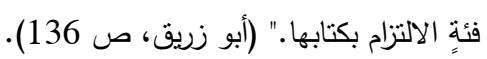

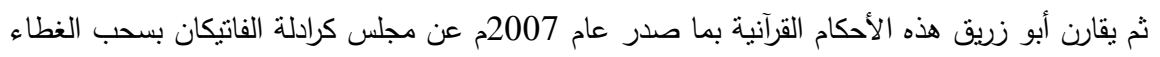

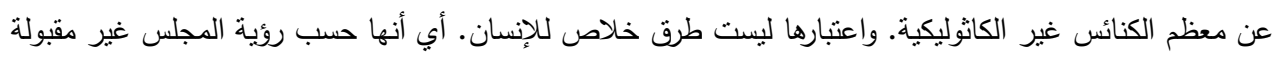

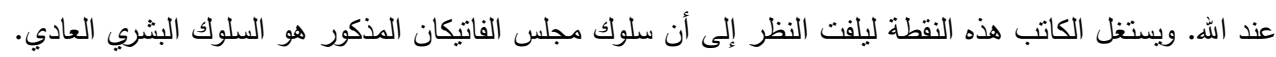

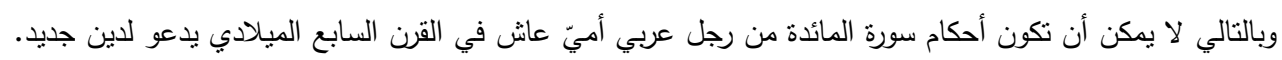

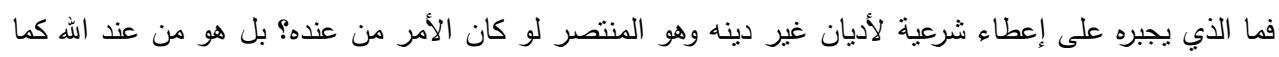

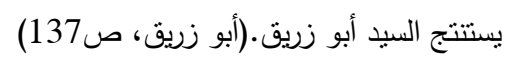

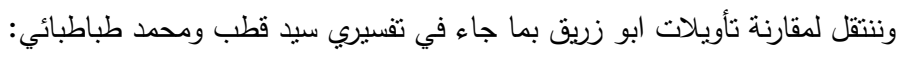

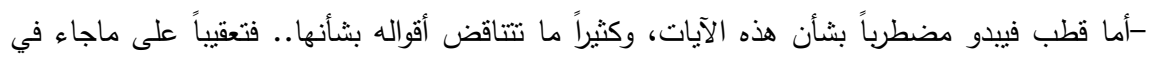

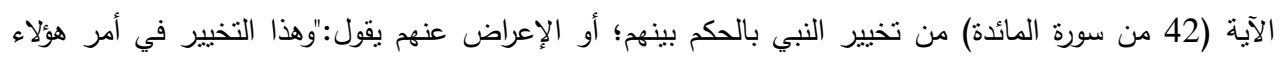

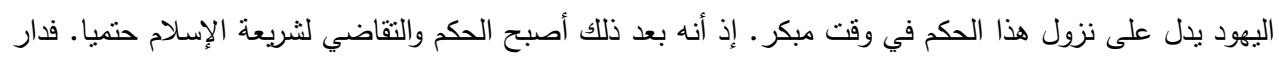

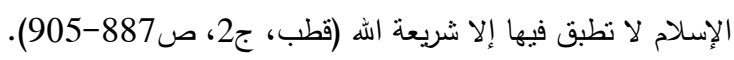
فكيف يكون التقاضي لثريعة الإسلام حتمياً ثم يسمح لهم بما سمحت به شرائعهم؟ 
وتفسيراً لقوله (45) آية النفس بالنفس يقول:" وقد استقبيث هذه الأحكام الني نزلت بها النوراة في شريعة

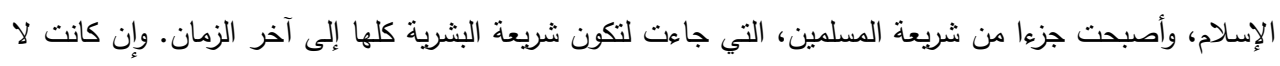

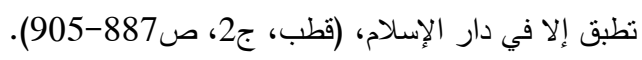
وتعقيبا على قوله تعالى بحق النصارى (وليحكم أهل الإنجيل بما أنزل الله فيه) يقول: "فالقاعدة هي الحكم

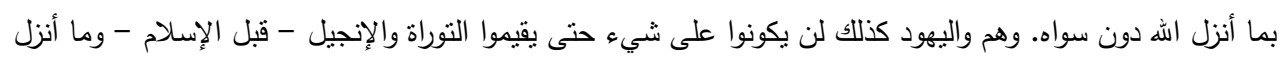

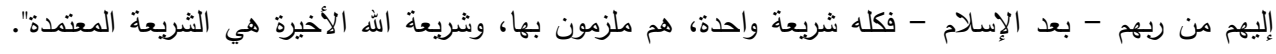
(قطب، ص، 745 المجلد الثاني).

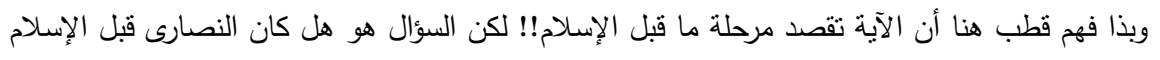

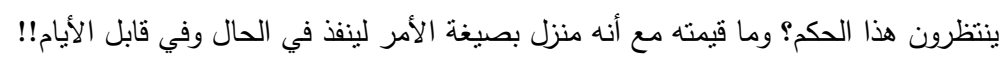

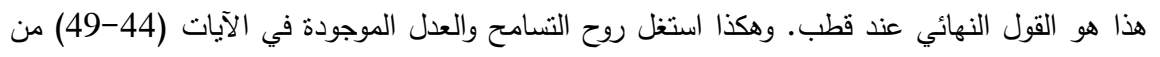

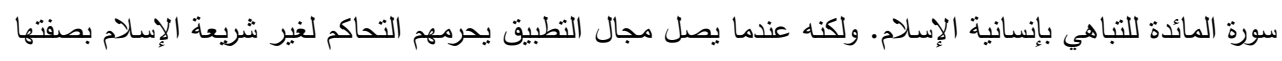

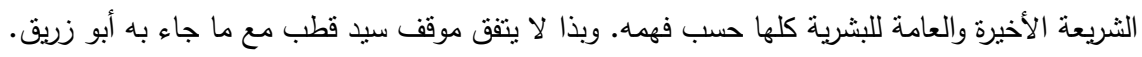

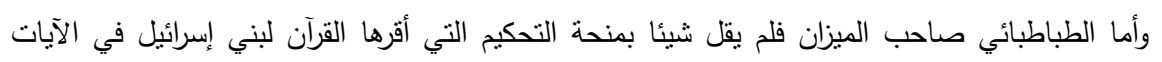

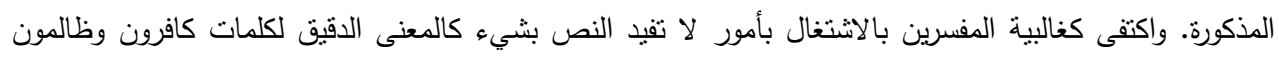

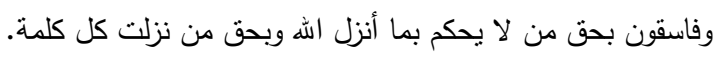

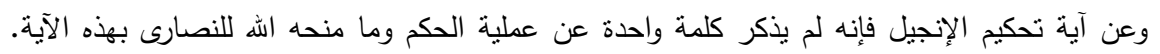

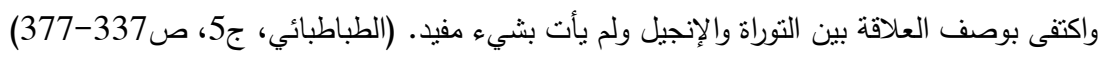

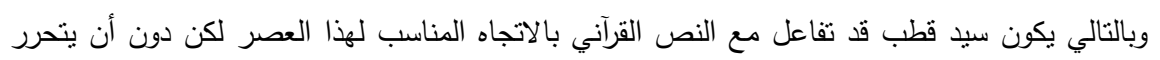

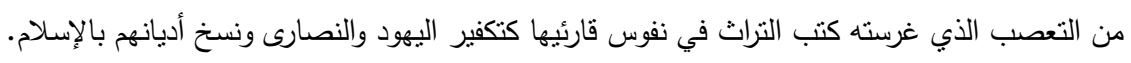

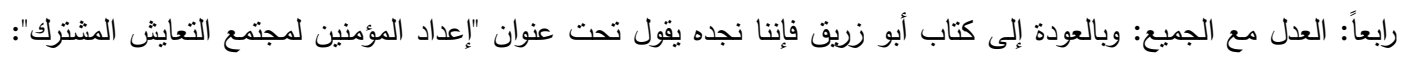

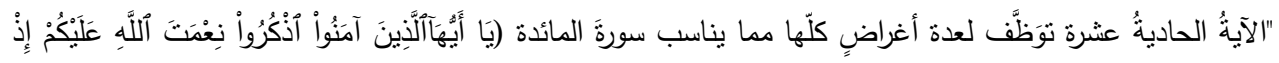

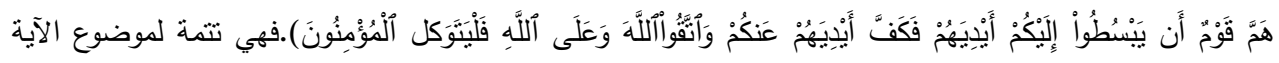

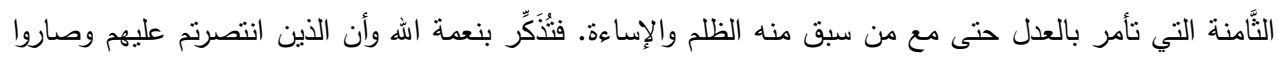

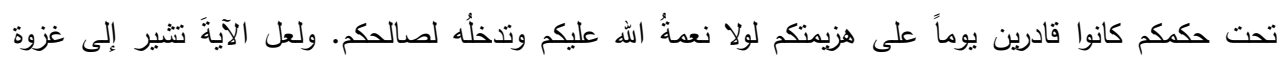

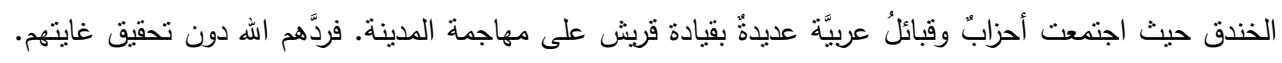

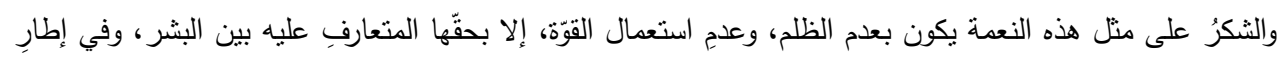

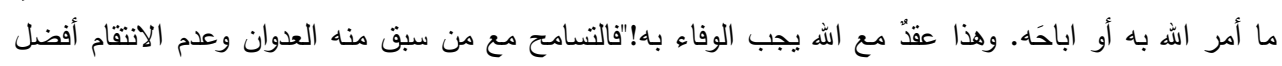

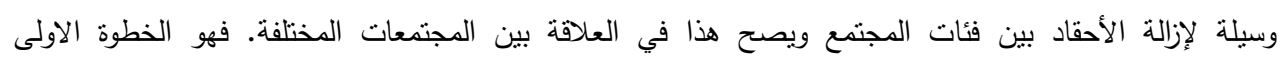

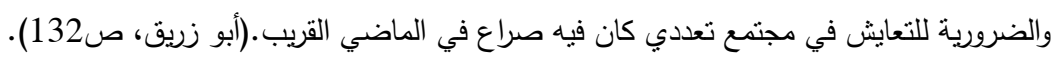

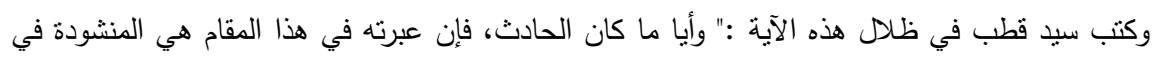

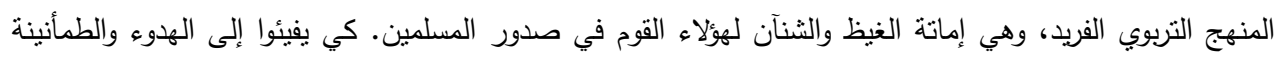

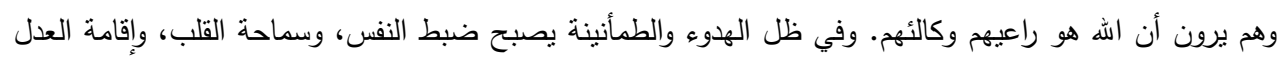

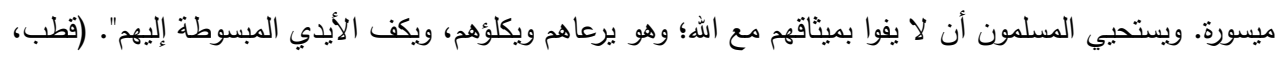

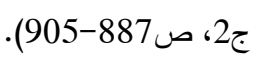


The Philosophy of Coexistence in the Interpretation of Al-Maidah Surah...

ولعل ما كتبه السيد أبو زريق كان أولى أن يوضع تحت الآية الثامنة كما فعل سيد قطب في الظلال إذ إذ الذيا

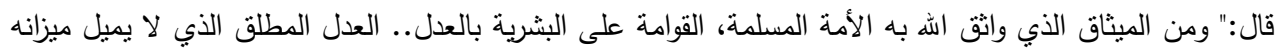

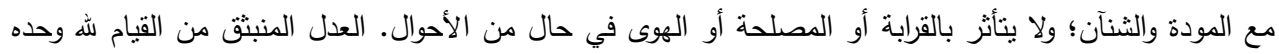

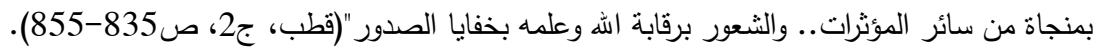

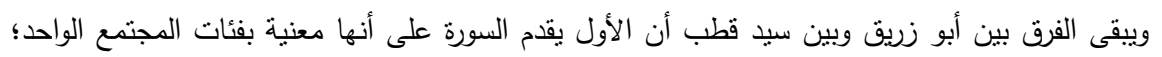

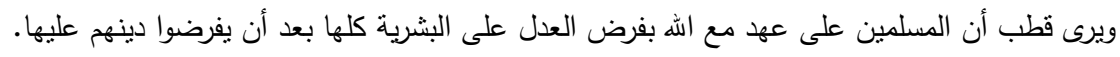

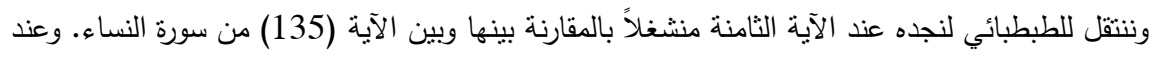
الآية الحادية عشرة موضوع فقرتتا هذه نجده منشغلا بمعنى النقوى والتوكل دون ربطهما بموضوع العدل والتعايش.

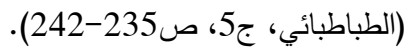

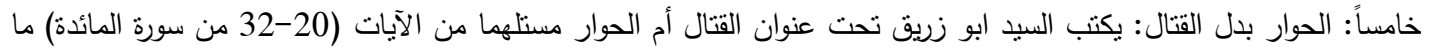

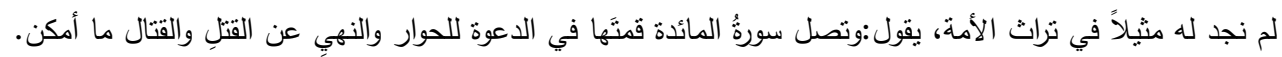

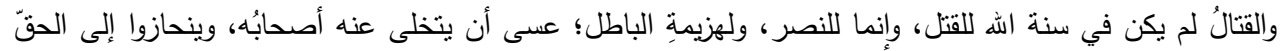

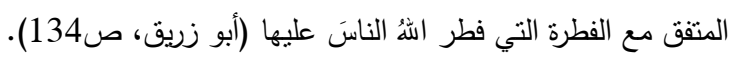

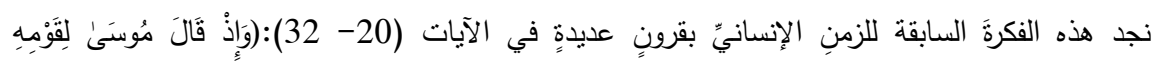

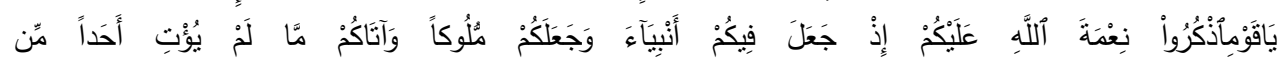

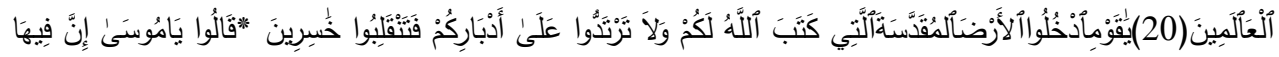

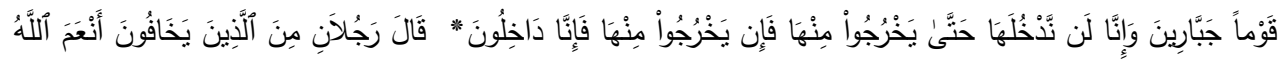

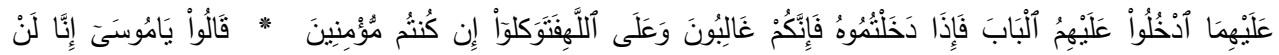

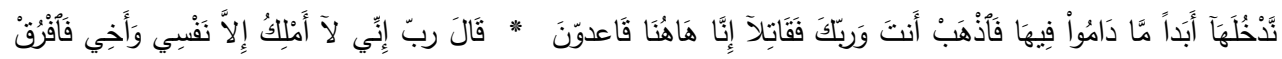

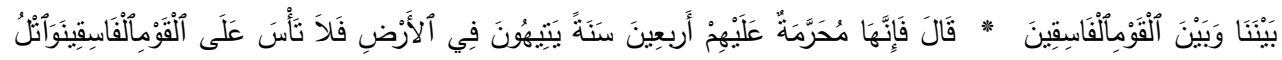

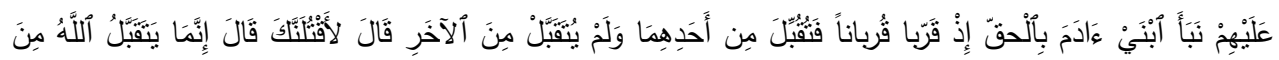

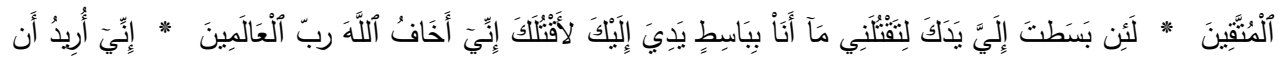

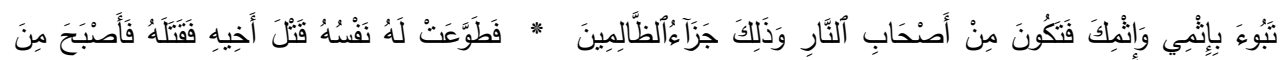

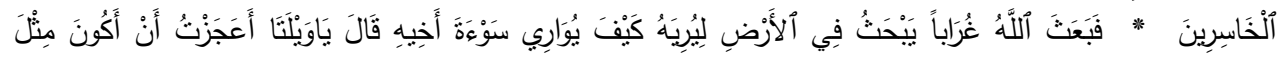

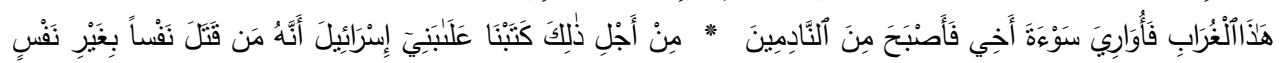

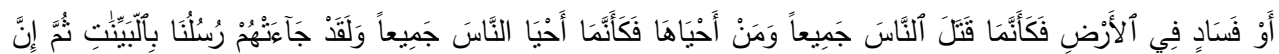

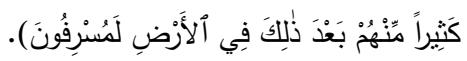

في الآيات (20-20 من سورة المائدة) نرى بني إسرائيل يعصون نبيهم، ويرفضون القتال لأنهم لا يقدرون

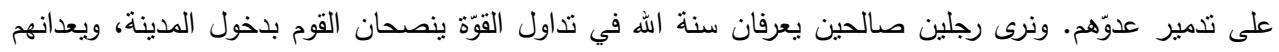

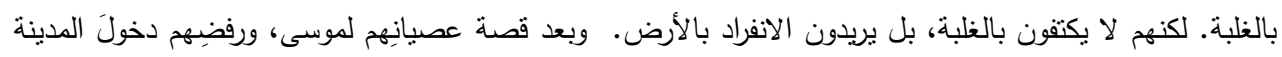

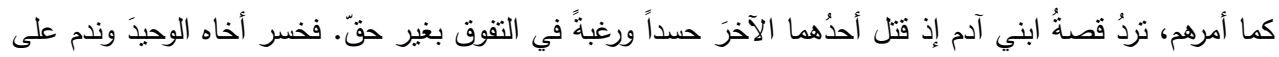

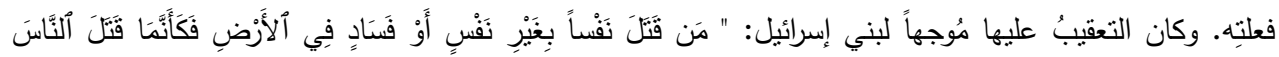

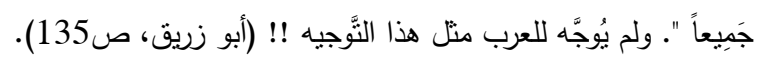


والقصتان تسيران في نفس الاتجاه. فهما حالةٌ واحدةٌ هي الرغبةُ بالقضاءٍ التامٌٍ على المنافس. وفي القصتين

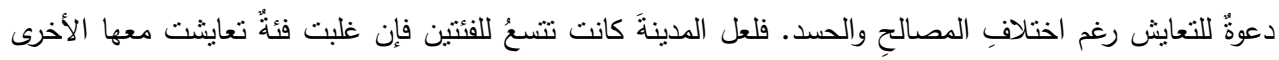

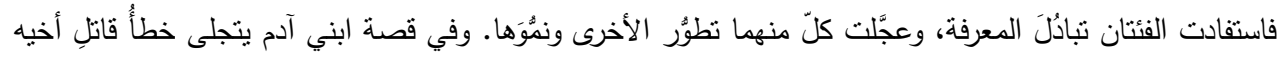

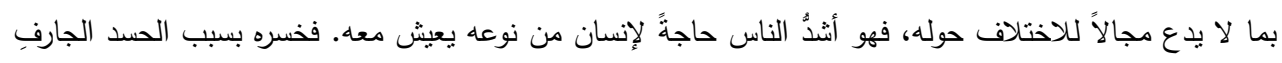

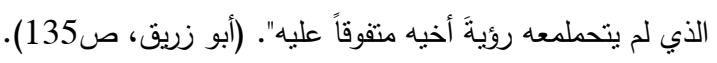

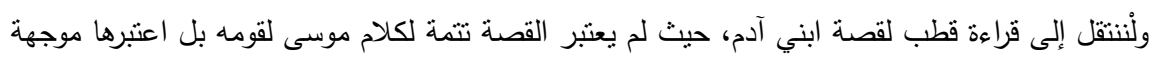

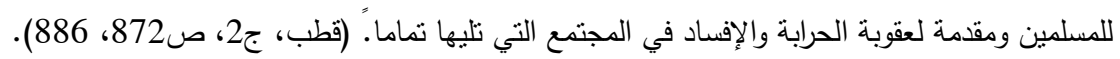

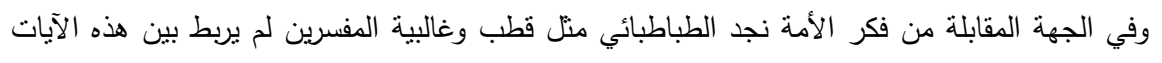

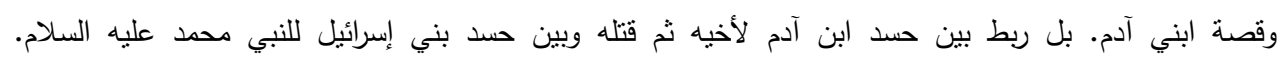

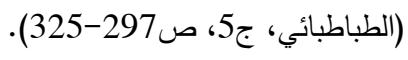

وحسب ابو زريق فإن قصة ابني آدم موجهة إلى موسى لينلوها على قومه. وحسب قطب والطباطبائي

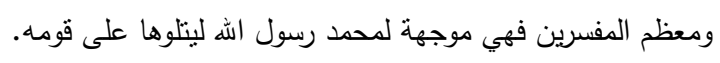

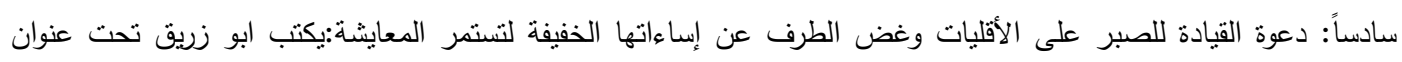

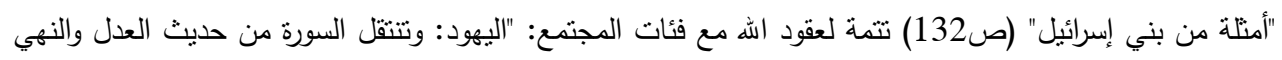

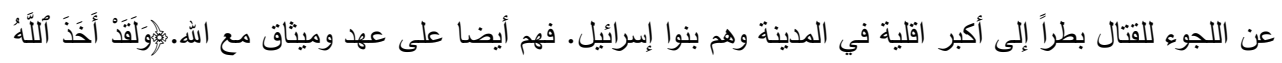

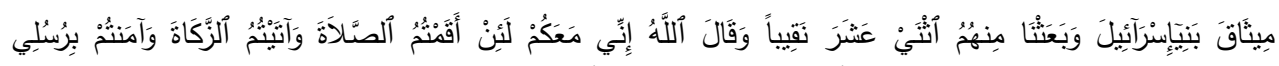

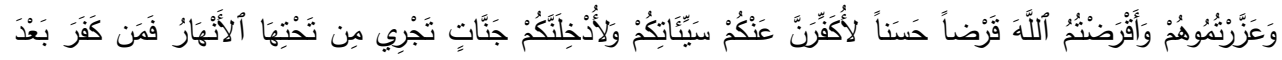

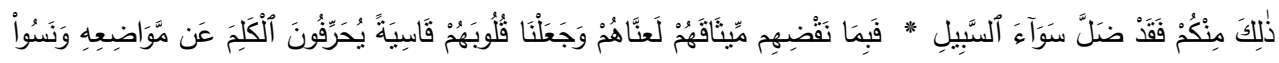

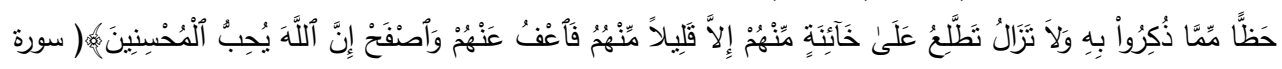

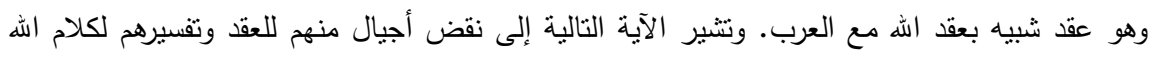

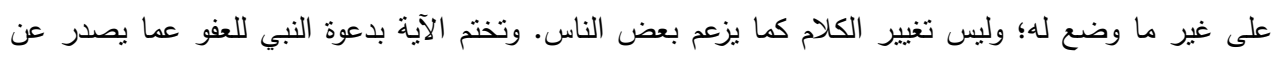

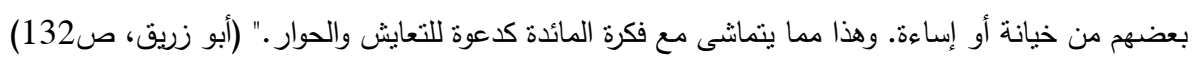

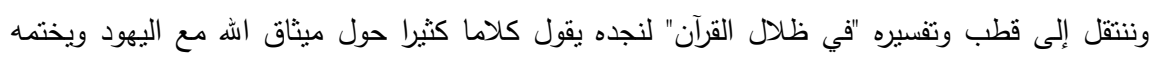

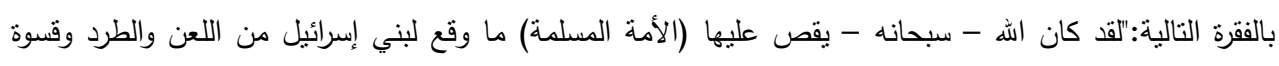

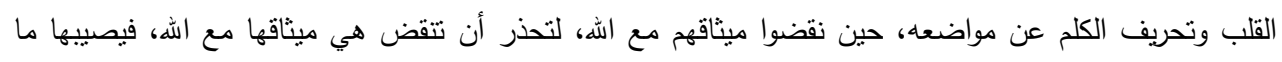

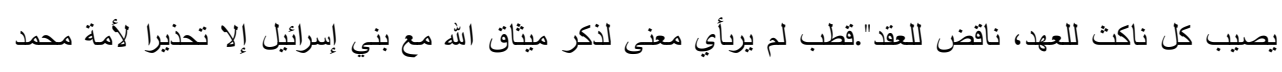

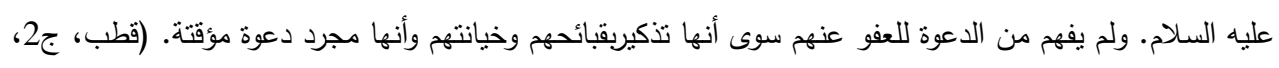

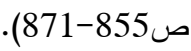
وأما الطباطبائي في تفسيره الميزان جاء أثند عليهم من سيد قطب في وصف نقضهم ونتائجه ولكنه لم يقل

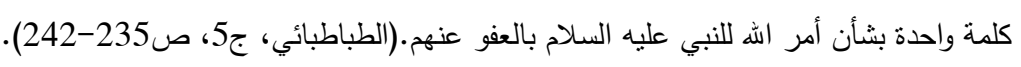

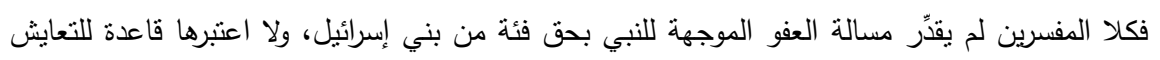

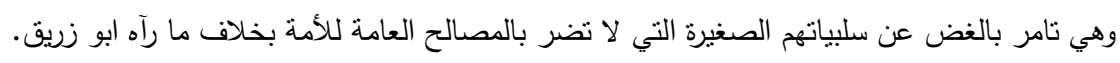


The Philosophy of Coexistence in the Interpretation of Al-Maidah Surah...

سابعاً: الأمنضمانة التعايش:نقرأ في قول أبو زريق "وفي مجتمعِ المائدة والحوار المتمدن لا بدَّمن الأمن لذلك تأني آياثُ الحرابة

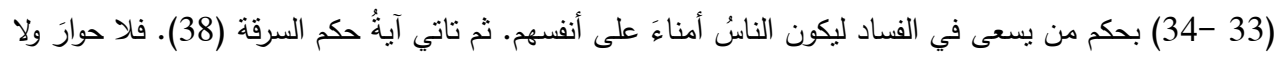

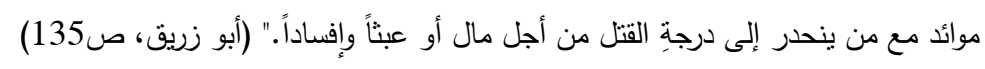

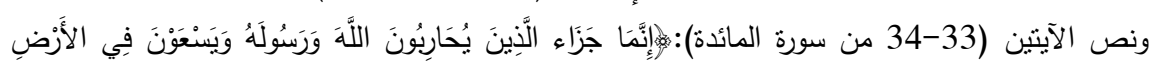

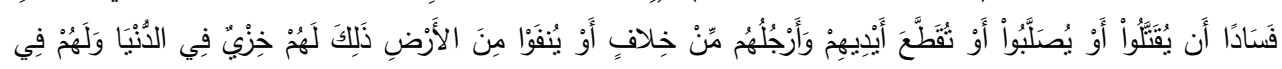

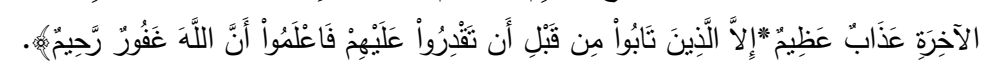

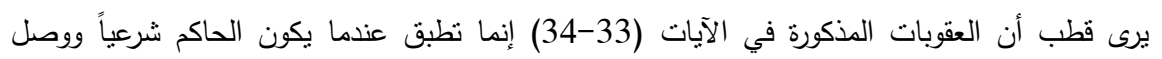

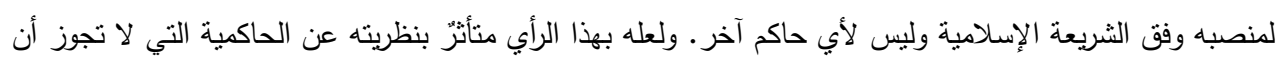

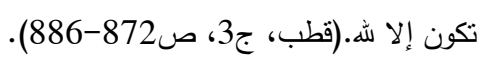
ويقول الطباطبائي في تفسيره الميزان: "فالمراد بالمحاربة والإفساد على ما هو الظاهر هو الإخلال بالأمن

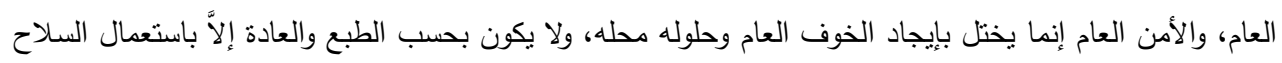

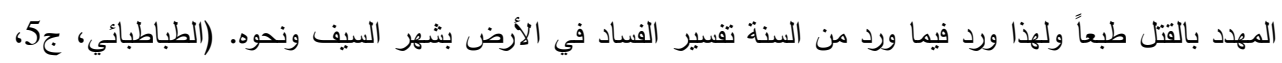

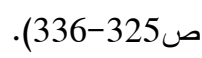
ولا نرى اختلافا بين الباحثين الثلاثة من الناحية العملية فلا شك أن أمن المجتمع واضح في التفسيرات

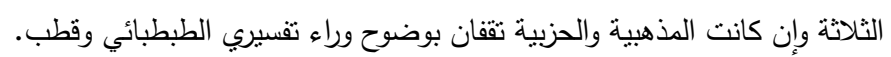

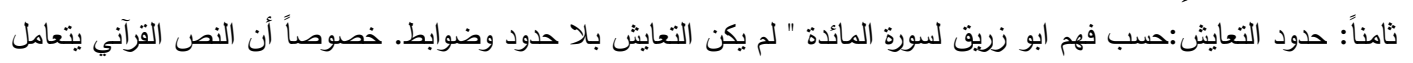

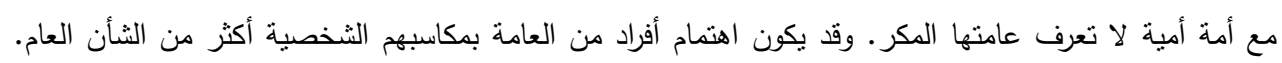

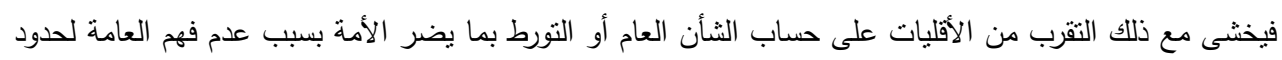

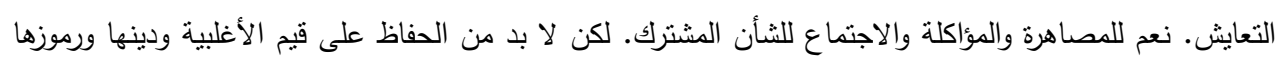

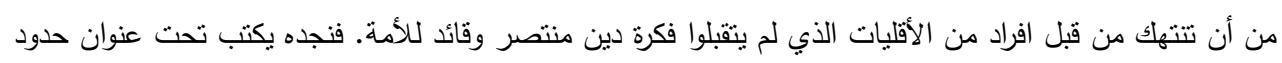

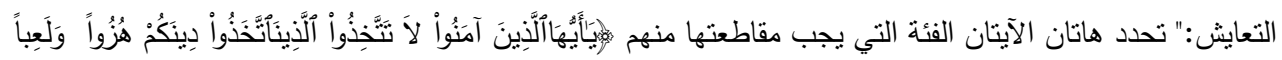

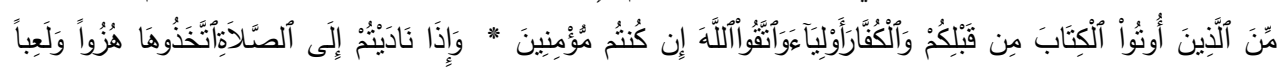

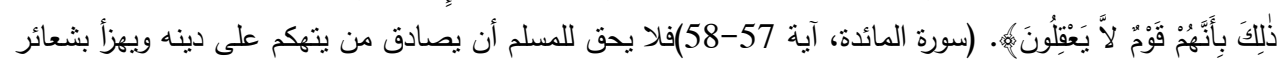

والآيات كما نرى تتحدث عن فئة قليلة من أهل الكتاب تتهكم على شعائر الدين لنقص في عقلها. وليس

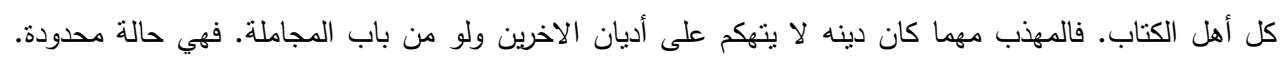

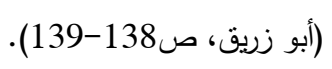

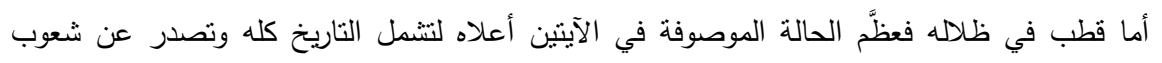

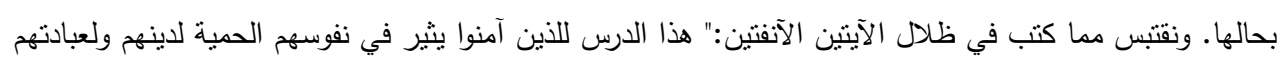

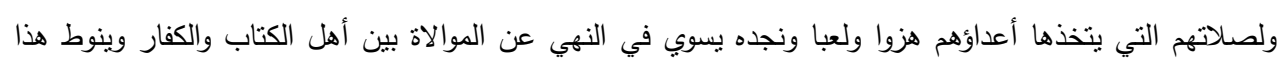

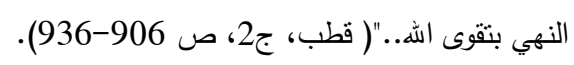

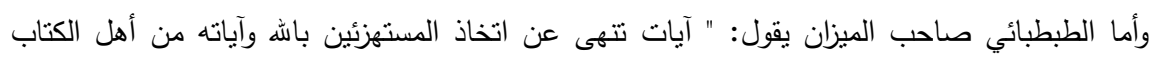

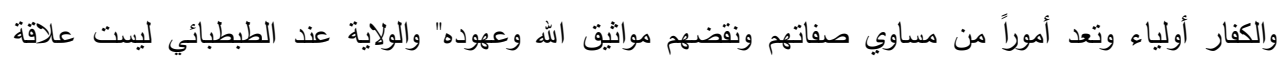


محسوبة مقيدة بظاهرها بل هي تمازج روحي وإيثار يندر تحقيقه إلا بين أعضاء الأخويات الدينية ذوات الصفة

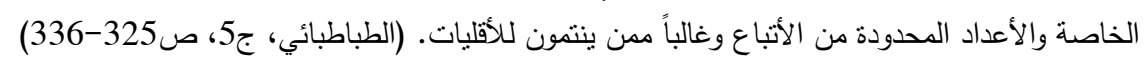

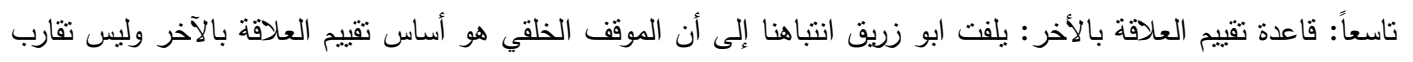

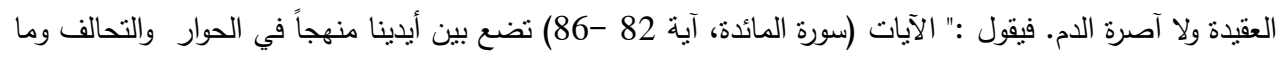

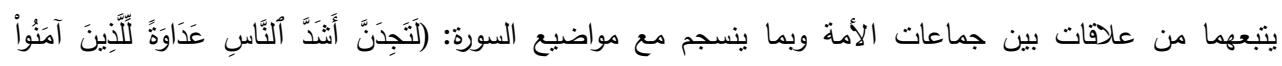

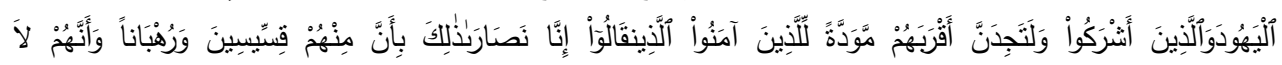

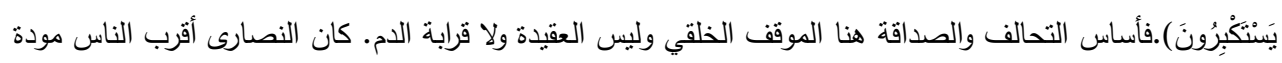

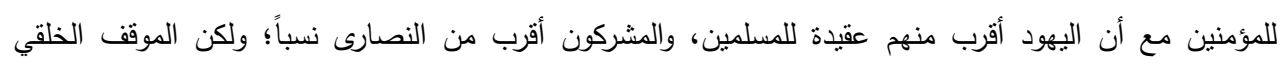

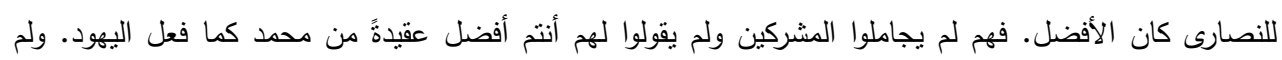

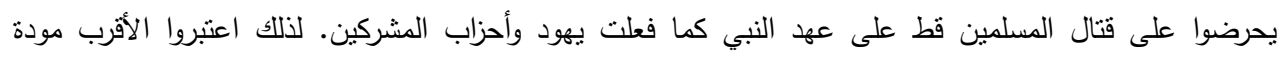

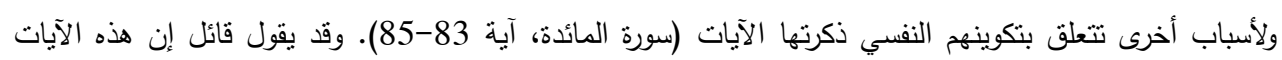

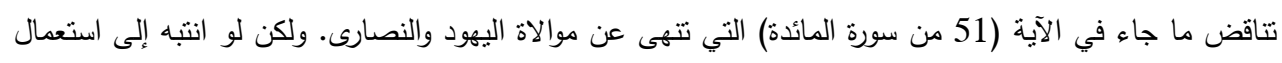

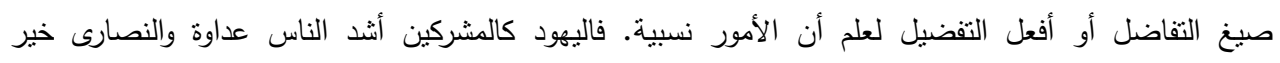

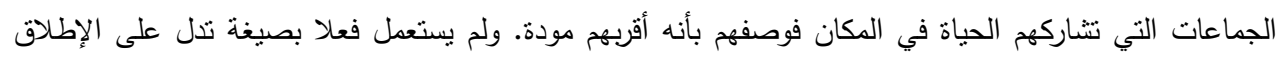

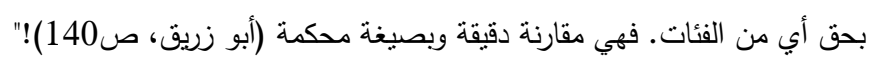

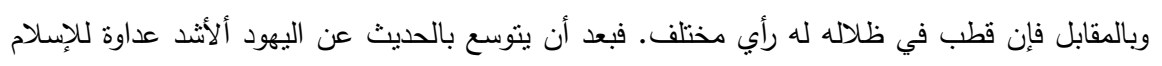

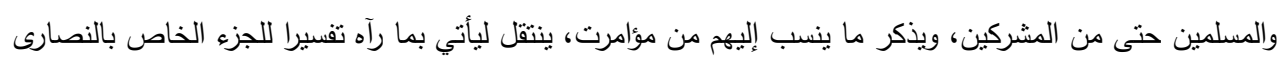

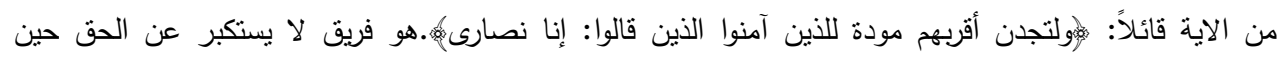

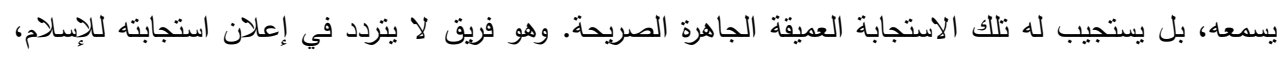

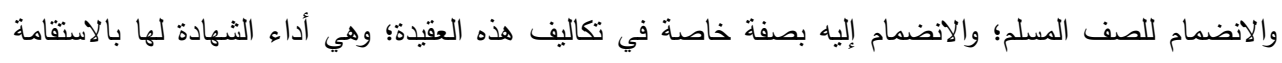

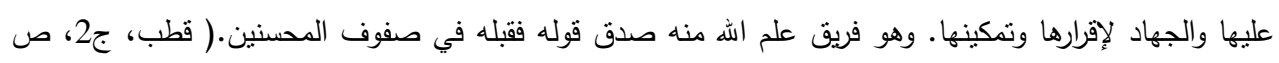

(968-959

وكتب الطبطبائي في الديزان كلاما كثيرا حول الآية وبدا مضطرباً في البداية وهو يقترب من رأي سيد

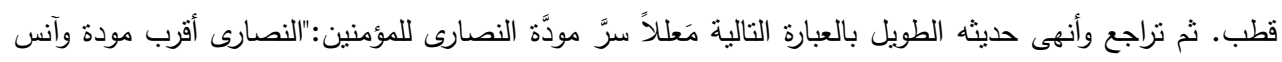

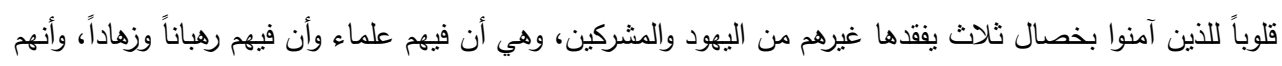

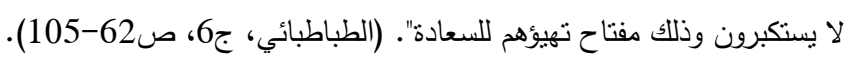

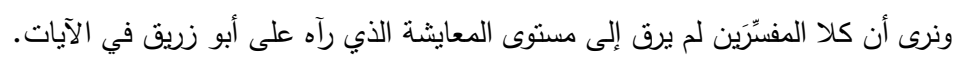

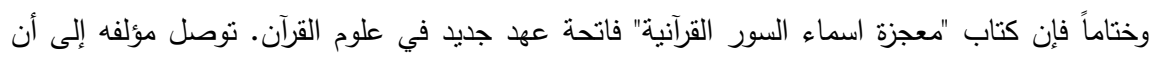

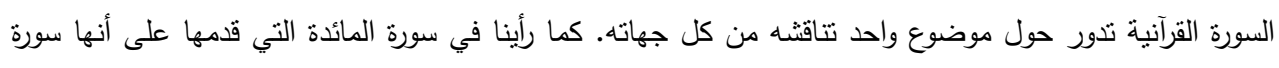

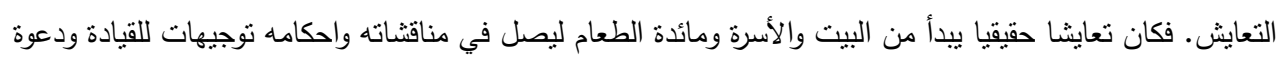

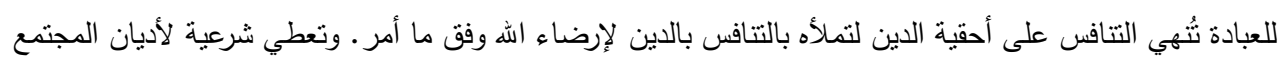

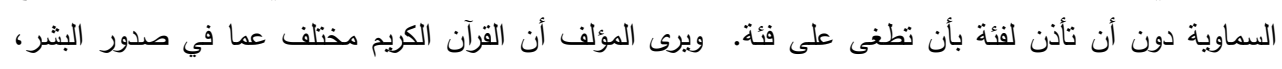

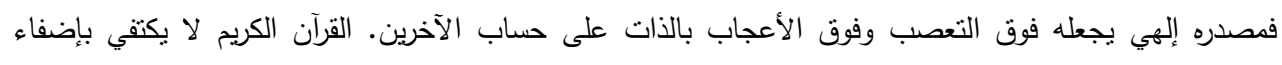

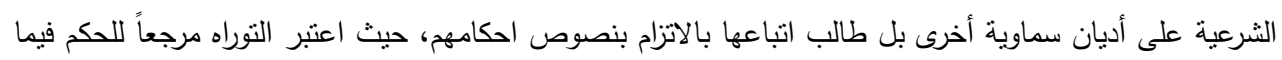


The Philosophy of Coexistence in the Interpretation of Al-Maidah Surah...

يتعلق بيني اسرائيل مع وجود القرآن الكريم والنبي محمد صلى الله عليه وسلم، وكنلك موقفه الكريم مع الانجيل فاعنبراه

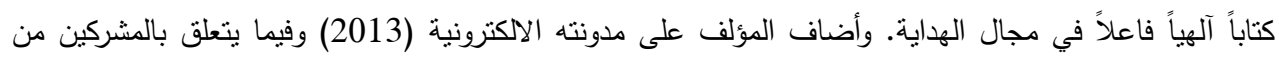

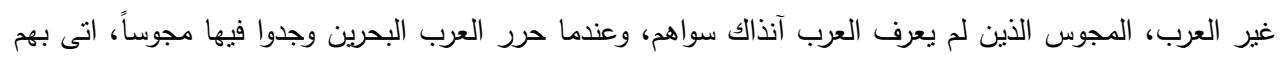

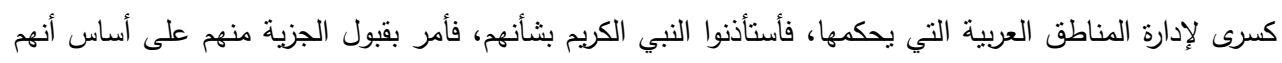

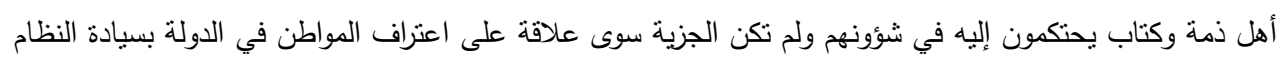
الجديد.

ومما لم نعرضه في هذه الورقة ما ذكره المؤلف من نعايش الإنسان مع البيئة بعدل وسلاسة وذلك في الإني

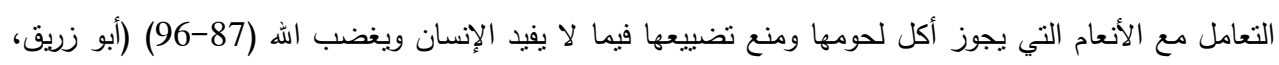

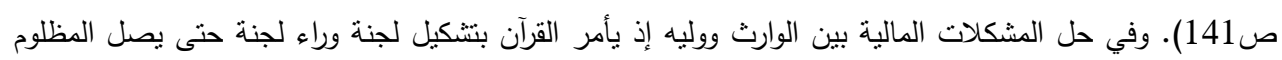

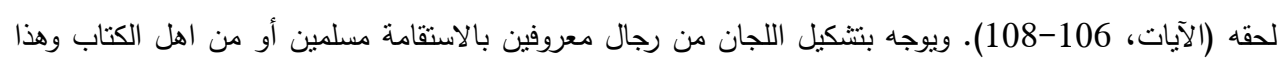

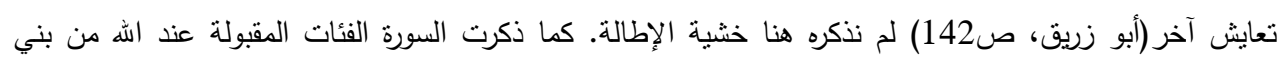

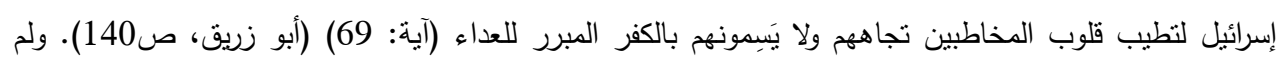

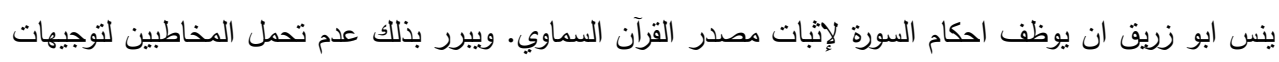

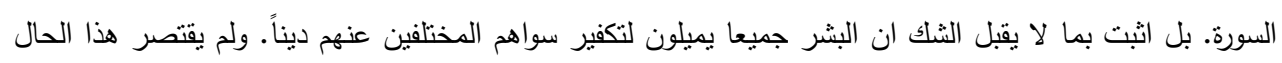

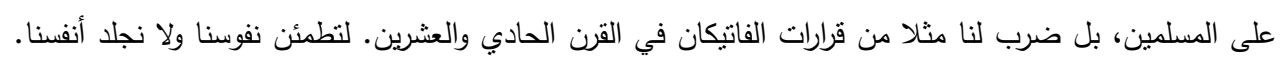

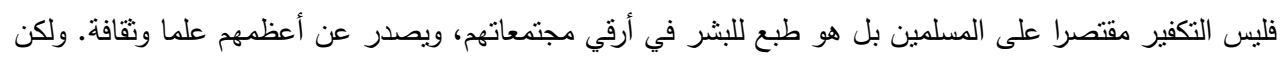
القرآن بمصدره الإلهي جاء بالحق والعدل وهو يدعو لتعايش مختلفي الأديان.

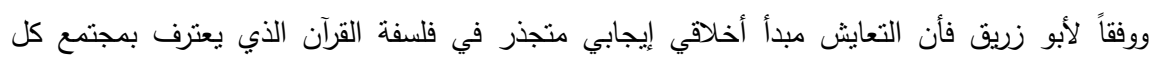

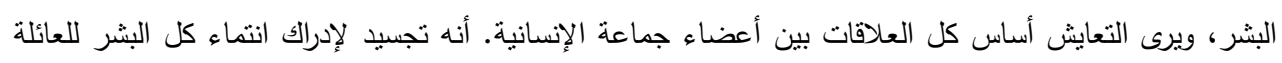

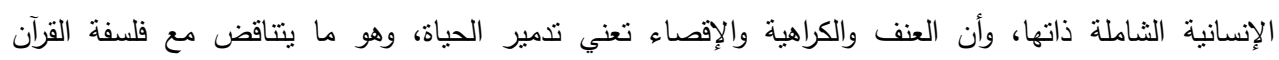




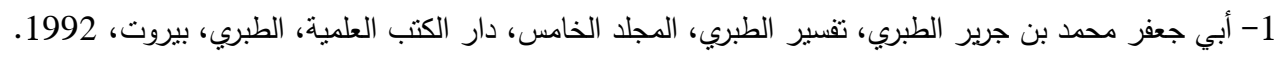

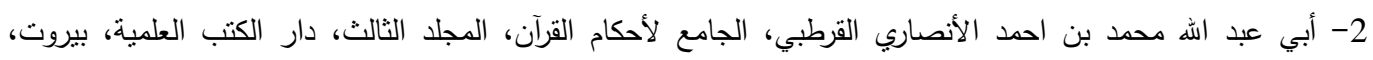

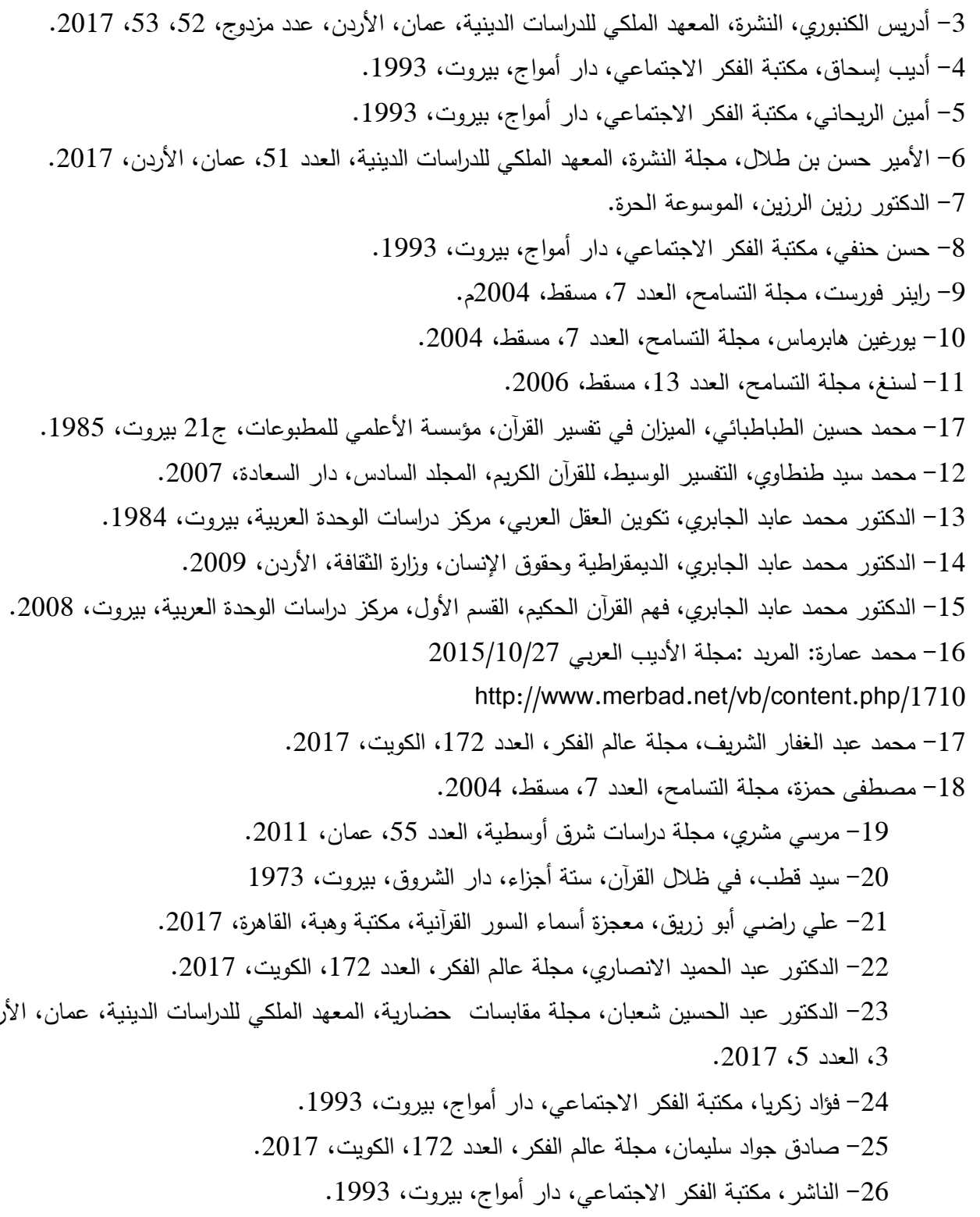


The Philosophy of Coexistence in the Interpretation of Al-Maidah Surah...

$$
\begin{aligned}
& \text { مراجع أخرى: } \\
& \text { 1- أبي الفداء إسماعيل بن كثير، تفسير ابن كثير، دار الصابوني، القاهرة. }
\end{aligned}
$$

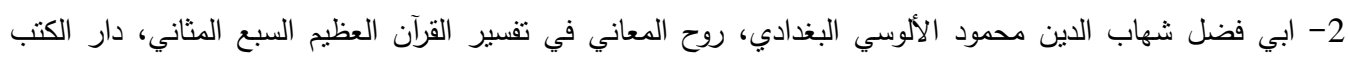

$$
\begin{aligned}
& \text { العلمية، بيروت، } 2005 . \\
& \text { 3- أبي السعود، محمد بن محمد بن مصطفى العمادي، تفسير أبي السعود، دار الكتب العلمية، بيروت، } 19971 . \\
& \text { 4- الدكتور أحمد نوفل وآخرين، الثقافة الإسلامية وقضايا العصر ، دار الحامد للنشر والتوزيع، عمان، 2013. } \\
& \text { 5- جار اله محمود بين عمر الزمخري، الكثاف عن حقائق التنزيل وعيون الأقاويل في وجوه التأويل، الجزء الأول مكتبة دأنة } \\
& \text { مصر، 2010م. } \\
& \text { 6- جيرالد جيمس تومر ، حكمة الثرق وعلومه، عالم المعرفة الكويت، } 2017 . \\
& \text { 7- الثيخ طنطاوي جوهري، الجواهر في تقسير القرآن الكريم، المكتبة الإسلامية، } 1974 .
\end{aligned}
$$

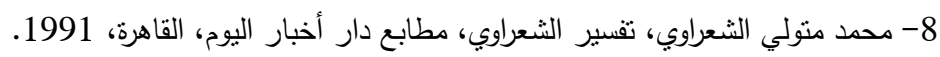

$$
\begin{aligned}
& \text { 9- المهدي المنجرة، الإهانة في عهد الميقا إمبريالية، المركز الثقافي العربي، الدار البيضاء، داءي، } 2004 .
\end{aligned}
$$

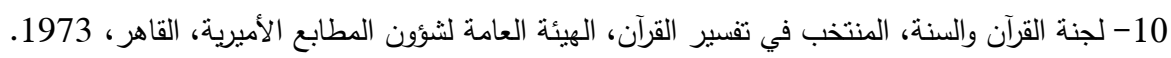

$$
\begin{aligned}
& \text { 11- كمال طيرشي، وذلك في مقاله المنشور على صفحة مؤمنون بلا حدود بتاريخ } 20 \text { مارس 2015، نقلاً عن: }
\end{aligned}
$$

. Edgar Morin, introduction a une politique de I'homme, édition du seuil, paris, 1965, p92 http://www.mominoun.com/tags/1111: ورابط مقالته

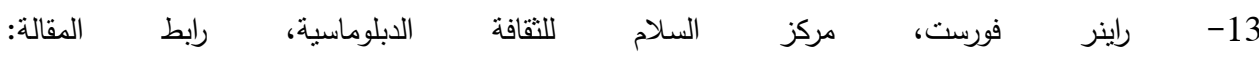

$$
\begin{aligned}
& \text { http://www.siironline.org/alabwab/diplomacy-center/035.html }
\end{aligned}
$$

المراجع باللغة الإنجليزية

\section{References}

1- Huston Smith, the World's Religions, ترجمة سعد رستم، دار الجسور الثقافية، حلب 2005

2- Luciano Floridi, The Fourth Revolution, Oxford University Press, 2014.

3- Maryam Jameelah, Islam in Theory and practice, Taj Company, Delhi, 1983.

4- Mohammad Hashim kamali, Freedom of Expression in Islam Islamic Texts society, Cambridge, 1997.

5- Maulana Muhammad Ali, Religion of Islam, Book crafters, Chelsea, Michigan, 1990.

6- Norman Daniel, Islam and the West, Ednburgh University press, 1966.

7- Dr. Saeed Ismaeel, The Relationship Between Muslims and Non Muslims, Al Attique In'I Islamic publications, Toronto, 2000.

8- Dr. Shafique. Ali Khan, Freedom of Thought and Islam, Adam publisher, Delhi, 1999. 